\title{
The safety net role of inland fishing in the subsistence strategy of multi-active forest dwellers in southern Cameroon
}

Pêche en eau douce : filet de sécurité de la stratégie de subsistance de peuples forestiers pluriactifs du sud Cameroun

Edmond Dounias, Serge Cogels, Serges Mvé Mbida and Stéphanie Carrière

\section{OpenEdition}

\section{Journals}

\section{Electronic version}

URL: http://journals.openedition.org/ethnoecologie/2844

DOI: $10.4000 /$ ethnoecologie.2844

ISSN: 2267-2419

\section{Publisher}

Laboratoire Eco-anthropologie et Ethnobiologie

\section{Electronic reference}

Edmond Dounias, Serge Cogels, Serges Mvé Mbida and Stéphanie Carrière, « The safety net role of inland fishing in the subsistence strategy of multi-active forest dwellers in southern Cameroon », Revue d'ethnoécologie [Online], 10 | 2016, Online since 31 December 2016, connection on 30 April 2019. URL : http://journals.openedition.org/ethnoecologie/2844; DOI : 10.4000/ethnoecologie.2844

This text was automatically generated on 30 April 2019.

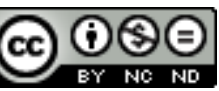

Revue d'ethnoécologie est mis à disposition selon les termes de la licence Creative Commons Attribution - Pas d'Utilisation Commerciale - Pas de Modification 4.0 International. 


\title{
The safety net role of inland fishing in the subsistence strategy of multi- active forest dwellers in southern Cameroon
}

\author{
Pêche en eau douce : filet de sécurité de la stratégie de subsistance de peuples \\ forestiers pluriactifs du sud Cameroun
}

Edmond Dounias, Serge Cogels, Serges Mvé Mbida and Stéphanie Carrière

\section{Introduction}

1 For many ethnic groups of the Congo Basin - for instance the Batanga of Cameroon (Pagezy \& Nzouango 1998), the Ntomba of DRC (Pagezy 1988) and the Likouba of Republic of Congo (Comptour et al. this issue) - inland capture fisheries constitute a prominent source of cash income. When referring to those small-scale fisherfolks whose livelihoods and revenues primarily depend on fishing activities, experts of economic development generally discredit fishing as a poverty trap: Even though fish is recognized as a major source of animal protein for millions of Central African forest dwellers, there is a rampant consensus in perceiving these artisanal fisheries as a stagnant, low-productivity and backward informal sector (Welcomme 1975, Platteau 1989, Chauveau et al. 2000, Smith et al. 2005, Béné et al. 2009, Welcomme et al. 2010). A telltale expression of this negative perception is that inland fishing appears only marginally in Poverty Reduction Strategy Papers (Thorpe et al. 2005) and is seldom considered as a means of rural development (Crean \& Symes 1996, Pauly 1997, Allison \& Ellis 2001, Béné 2003). Even if recent years have seen signs of a nascent interest for inland capture fisheries amongst the development community (Paugy et al. 2011, Welcomme 2011, De Graaf et al. 2015, Oishi 
\& Hagiwara 2015) fishing remains ignored in the current debates on rural economy, propoor growth or economic development.

Besides the obvious paucity of reliable data and scientific literature available on these fisheries, the recurrent arguments that are put forward to explain the poor situation of small-scale inland fisheries are the spatial diffuseness of fishing activities, and the fact that a significant part of the fish production is not commercialized or is marketed through informal channels - thus not properly reflected in national economic statistics. Fishing is seen as a high-risk occupation, prone to seasonal and cyclical fluctuations in stock size and location, some of which are judged highly unpredictable in occurrence (Allison \& Ellis 2001).

3 The goal of this paper is to stress that what is presumably presented as handicaps of fishing for the livelihoods of fulltime inland fisherfolks is in fact valorized as decisive advantages by the many forest dwellers who are only part-time fishers and who rely on a great diversity of subsistence and income-generating activities. The livelihoods of a great majority of forest dwellers in the Congo Basin are sustained by multi-active land use systems, which purposely combine a diversity of hunting, trapping, gathering and fishing activities, as complements of a predominant slash-and-burn agriculture (Delvingt 2001).

This unobtrusive yet essential role of inland fishing is illustrated through a combination of case studies carried out in the 1990s amongst two Fang speaking societies: the Mvae and the Ntumu of the Ntem watershed in southern coastal Cameroon (Figure 1). These two neighboring groups have in common with many small-scale farmers of the Congo Basin the fact that fishing is not their most salient domain of production. Nevertheless they have acquired a remarkable expertise in fishing, notably through a diversity of fishing methods and flexible socio-ecological conditions of practice that are mediated by the incredible vascularity of the hydrographic network. The paper will describe the very diverse fishing methods that take advantage of seasonality and of a mosaic of water microhabitats that are home for a rich ichthyofauna. This art of fishing involves in a complementary way all the members of the community - young and old, of both genders, in solo, in pairs or in larger groups. The paper aims to point out that the vast range of fishing possibilities ensures continuous protein intakes all over the year and establishes wild fishery as a real safety net: fishing can provide - in all circumstances and in sufficient quantities - resources that are culturally valued, that are an appreciable extra source of income, and that make a decisive contribution to local diets. 
Figure 1: Ntem watershed in southern Cameroon and ombrothermic profiles for the main cities

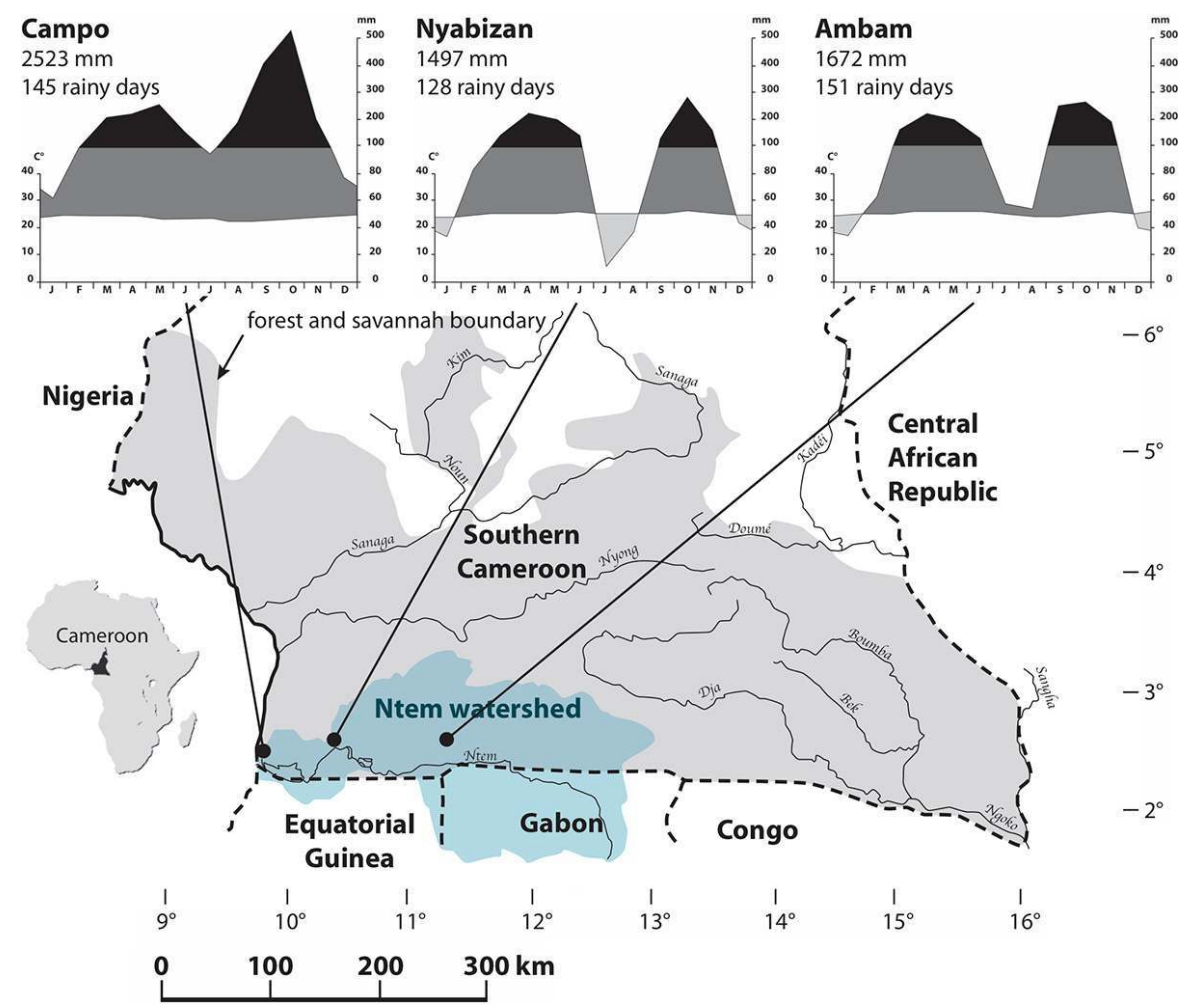

ADAPTED FROM DOUNIAS 1993

\section{The Ntem watershed and its peoples}

Situated in the southwestern coastal part of Cameroon and straddling the borders with Equatorial Guinea and Gabon (Figure 1), the Ntem watershed is home for a remarkable faunal richness that justified that the entire area of Campo district on its western coastal part was decreed a faunal reserve as early as in 1932 (Gartlan 1989). In the late 1990s, the reserve was downgraded along with the establishment of a much broader protected area, the Campo-Ma'an National Park (http://www.crea-africa.org/mediaresources/files/ Documentos/Actualizaci\%C3\%B3n\%2009/fs-campo-maan-cameroun.pdf), covering the major part of the Ntem watershed. This park is a host for 390 species of invertebrates, 249 species of freshwater fishes, 80 species of large and medium sized mammals, 122 species of reptiles, and 302 species of birds. The predominant original vegetation of the study area is classified as transitional between semi-deciduous forest of areas to the north and the evergreen Congolese rainforest found to the south and east, with many tree species typical of old secondary forests (Letouzey 1985). The overall climate type is four-seasons equatorial: two rainy seasons alternate respectively with two dry seasons. Depending on the location, the average annual rainfall varies between 1,400 and 2,500 $\mathrm{mm}$ and is distributed over 128 to 151 rainy days; the mean monthly temperature is $25.6 \mathrm{C}^{\circ}\left( \pm 3.3 \mathrm{C}^{\circ}\right)$. By contrast to the coastal side and the far east side of the Ntem watershed that register their most pronounced dry season from November to February, the driest period affecting the center part of the watershed - commonly called the Ntem loop because the river divides into up to four distinct branches before engaging into a single corridor of 
rapids and dividing again until reaching its final estuary (Figure 2) - falls from June to August.

The Mvae and the Ntumu people who are the main inhabitants of the Cameroonian part of the Ntem watershed (Figure 2) are included in a continuum of five ethnic groups namely the Fang sensu stricto, the Mvae, the Nzaman, the Ntumu, and the Okak - that compose the A75 'fang' linguistic group (Guthrie 1967-70). This group is characterized by a mutual comprehension between speakers of the distinctive ethnic groups. The Fang populations total around 40,000 in the southern part of Cameroon and are scattered widely and mixed with other linguistic groups over a province covering 47,000 square $\mathrm{km}$. Fang populations in Equatorial Guinea and northern Gabon are estimated around 55,000 and 150,000 people respectively.

Figure 2: Studied populations within the Ntem watershed

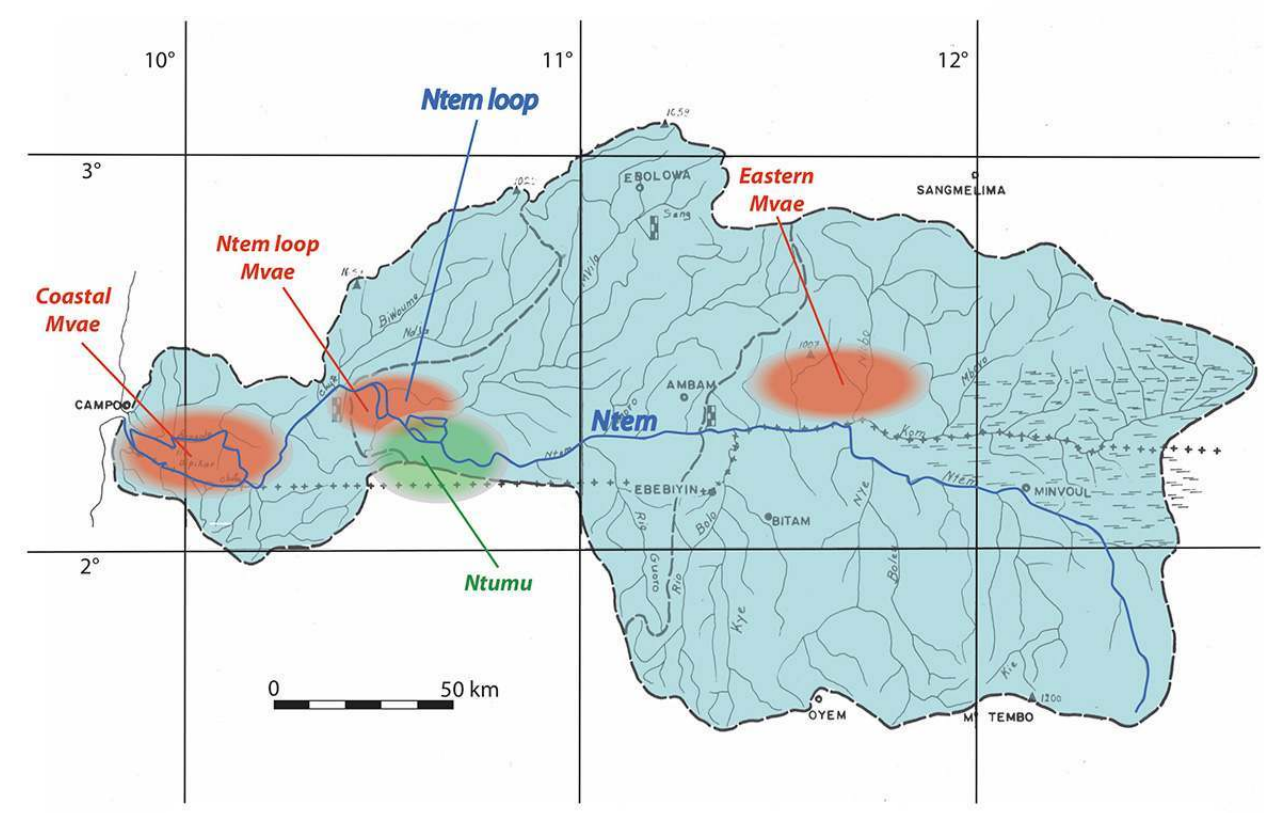

Background watershed profile is adapted from Olivry 1986

7 The Fang are basically slash-and-burn swiddeners who also gather various non-timber forest products, hunt, trap and fish. Their main cash incomes are ensured by the sales of food crops surpluses (Dounias 1996a, 1996b, Carrière et al. 2002a, 2002b) and cocoa and coffee as cash crops that are produced in agroforestry systems (Dounias \& Hladik 1996, Ménard et al. 2009, Ménard 2010), but also of bushmeat and freshwater fish (Dounias 2000, 2011, 2016). Before colonial times that began during the second half of the seventeenth century, the Fang ethnic groups were renowned as fierce and nomadic warriors who originated east of their current territory near the source of Ntem and Ivindo rivers. Their migrations were animated by a secular movement of search for salt towards the Atlantic coast (Alexandre 1965). Fang migrations were a part of a much broader Pahouin migration that occurred as diffuse and irregular step-by-step jumps of extended family groups, which punctuated their progression with local and repeated skirmishes (Alexandre 1965). The Pahouin migration was interrupted by the colonial penetration from the coast during the second half of the seventeenth century (Bostoen et al. 2015). Natural hydrography played a key role in shaping the spatial dynamics of these 
migrations, and water confluences mà'àn ${ }^{1}$ were favored sites for establishing settlements as they provided easy access to clean water and food but also to strategic ways to escape during these troubled wartimes (Dounias 1993). The term mà'àn is one of the most recurrent Fang toponyms that dot the various determining sites of their extended territories (Dounias \& Bahuchet 2000).

The main historical and ethnographic source regarding Fang fishing activities is a credit to Günter Tessmann (1884-1969). Tessmann was a tireless German explorer, collector and author who traveled in Cameroon, Spanish Guinea (currently Equatorial Guinea) and Gabon between 1904 and 1909, collecting many Fang objects on behalf of the museum of his hometown Lübeck, to which he donated his complete collection. His most achieved publication is a two-volume monograph on the Pahouin people, firstly released in 1913. This outstanding book is abundantly illustrated with drawings and photographs by Tessmann himself, and explores many aspects of Pahouin culture, language, history, religion, arts, ecology, and art of war. It includes a yet unequalled description of hunting and fishing activities. A few other drawing depicting fishing activities during the colonial times are reproduced from Augusto Panyella (1959), who was a Spanish anthropologist specialized on the study of the Fang Ntumu of Spanish Guinea.

The more recent ethnographic source about the Mvae is the credit to the lead author (Edmond Dounias) and corresponds to his doctoral fieldwork dedicated to the Mvae between 1984 and 1991 (Dounias 1993, 2011). He also studied the fishing activities of the Ntumu in 1994-1995 (Dounias 1995). Two of the other authors (Stéphanie Carrière and Serge Cogels) carried out ethnographic research between 1995 and 1998 in a couple of Ntumu villages located on the North bank of the Ntem river (Carrière 1999, 2003, Carrière \& Castro Carreno 2003, Cogels 2002). In 2015 and 2016, the last author (Serges Mvé Mbida) who is an ichthyologist, inventoried and identified the ichthyofauna in the Ntem loop.

After that the ethnographic studies presented in this paper had been conducted, the Ntem watershed and its periphery were exposed to massive conservation and development projects that are summarized in Figure 3 (see also Ménard 2010). These projects have drastically affected the physical environment, biodiversity and livelihoods in the study area. For instance, deforestation is known to change the seasonal flood regimes and to consequently threaten forest fish faunas (Welcomme 1975). Accordingly, some of the fishing activities that are described in this paper might no longer be in use today. 
Figure 3: Major development and conservation projects implemented in the studied area over the past 15 years. Background map courtesy from Google Earth on 21/08/2009

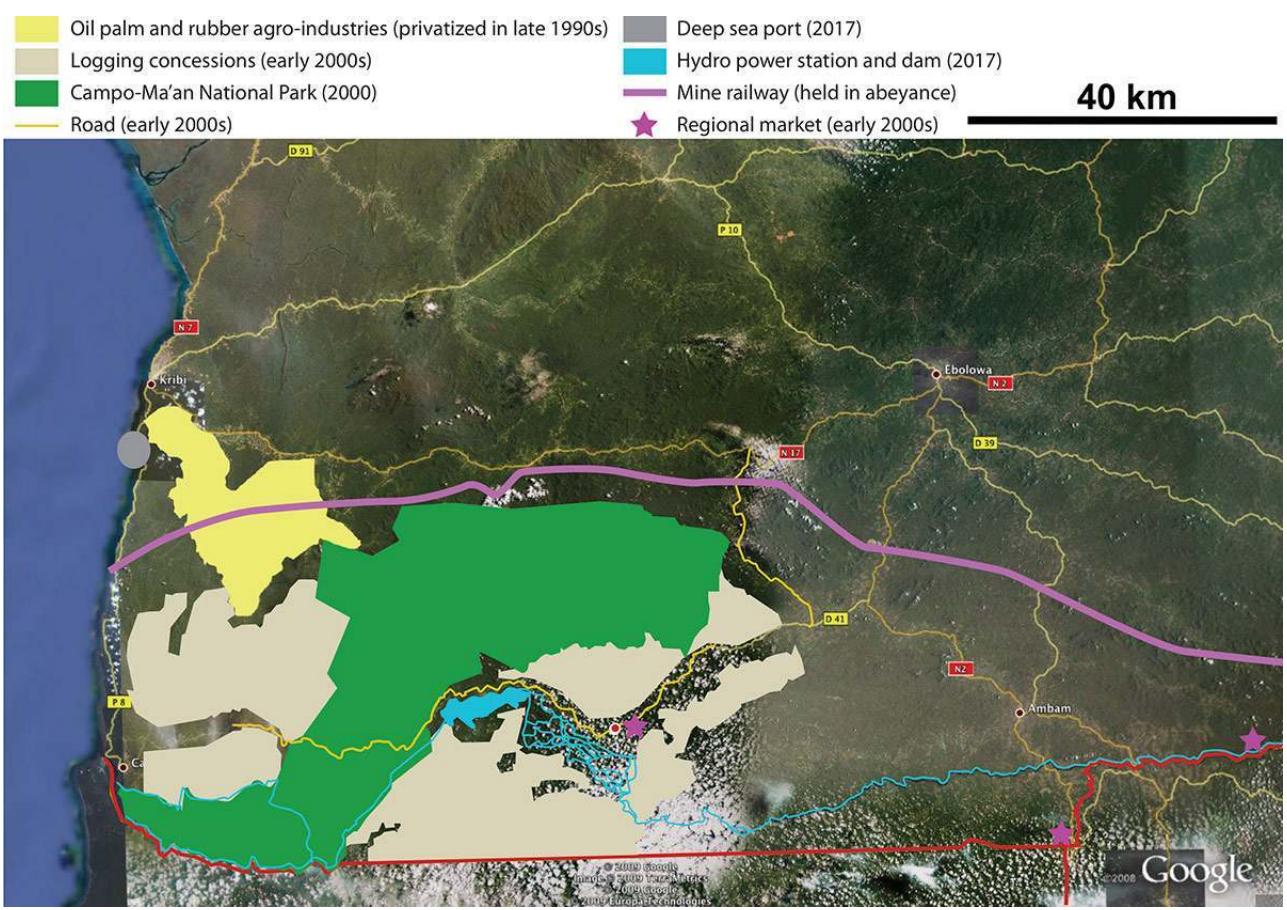

Updated from Menard et al. 2009

\section{Vascularized watershed and related diversity in fishing methods}

11 Freshwater resources of the Congo Basin rainforests are extremely diverse, and so are the ichthyological knowledge systems that are conceived by the indigenous fishers. Rainforest inland fishers take advantage of the densely vascularized watersheds whose innumerable ramifications - concentrated on very small areas - offer an incredible mosaic of very distinctive microhabitats. These microhabitats are dynamic and are constantly recombined in space and time. Each site is exploited on a seasonal basis, but the cumulative diversity of fishing spots ensures a continued fish production throughout the year.

12 The Mvae and the Ntumu recognize four main categories of inland watercourses (Figure 4) that dictate their fishing activities mvàno kwòs ('to fish'). Category 1 is composed of the dominant river njind $\boldsymbol{\varepsilon n}$, the Ntem river for the considered area. An area of the Ntem river divides into several branches $\mathbf{m b a ̂}$ ('̀̀-/mì-) that is occupied by the Ntumu (Figure 2 ). It is the selective ground for a few fishing methods that are not implemented elsewhere (Figure 5). This hydrographic particularity induces higher diversity in fishing methods used by the Ntumu and, to a lesser extent, by the Mvae who live in direct proximity with their Ntumu neighbors in the Ntem loop.

Category 2 is composed of secondary watercourses tójn (ò-/à-) along which seasonal fishing camps mvàn (⿳亠丷⿵冂-//mè-) are preferably established. Like the category 1 rivers, category 2 watercourses never dry up whatever the season. But the latter differ from the 
former by the absence of high gradient channels (rapids ǹndón, falls nkórásò ?) and by constantly moderate velocity of the current.

Category 3 refers to small streams vélé (è-/bì-) that seasonally dry up and in the beds of which the fishers can walk. However, transition between high to low flows in these streams can be very sudden and fishermen are obliged to use dugout (hereinafter simply referred to as 'canoes') canoes during seasonal floods.

Category 4 refers to areas of forest wetlands and flat river basins where low relief forests become seasonally inundated. In some parts of these swampy areas, patches of stagnant water édó? may persist after that the water has receded and up until the next flood. Category 4 wetlands and category 3 small streams are also exposed to subtle changes in the oxygen environment that are selectively used by the different fish families and they provide various suitable conditions for seasonal spawning. For instance, several catfishes of the Clariidae family take refuge in temporary burrows as an adaptive response to water deoxygenation during the dry season (Chapman et al. 1994) and some fishing methods have been conceived accordingly.

Figure 4: Mvae and Ntumu nomenclature of inland water categories

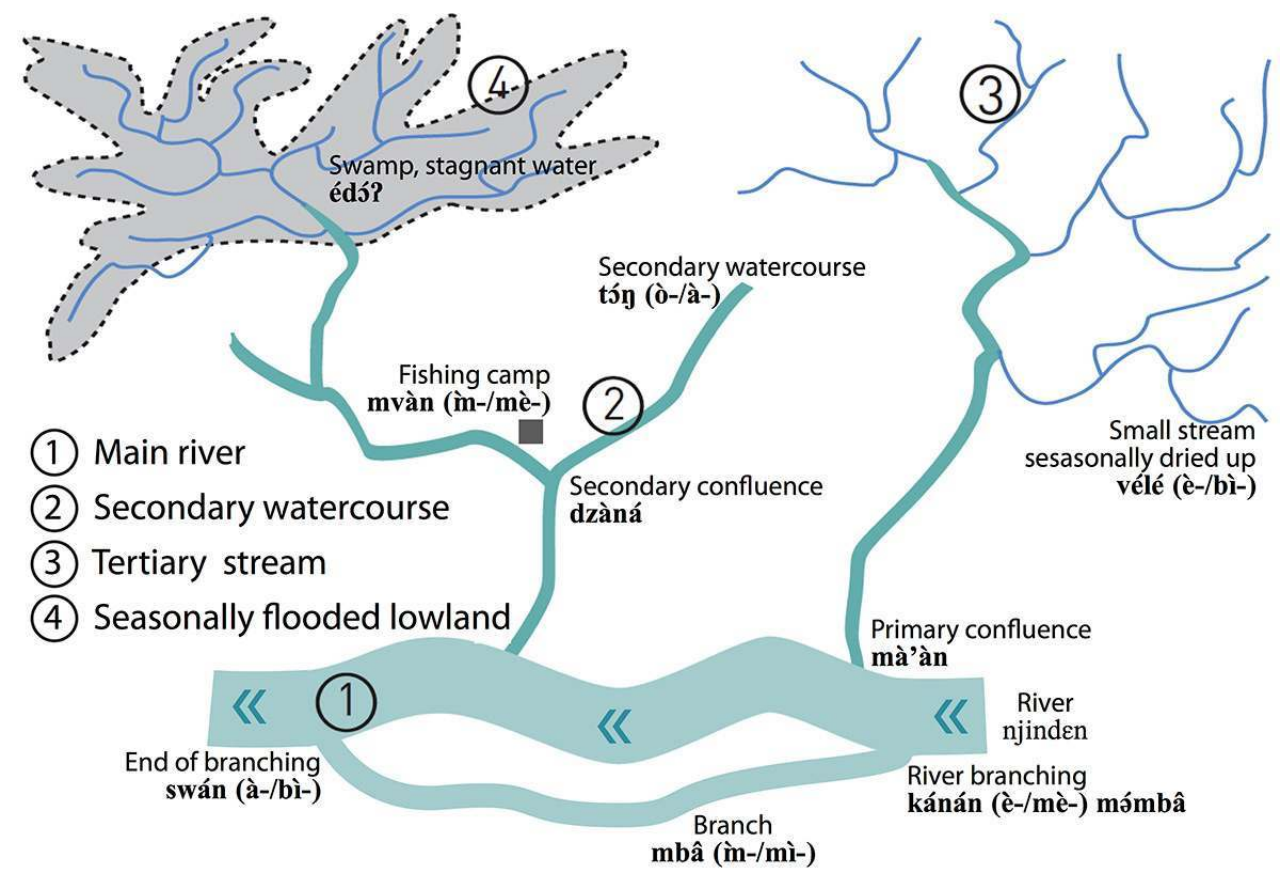


Figure 5: Contemporary and past fishing methods implemented among the Mvae and the Ntumu

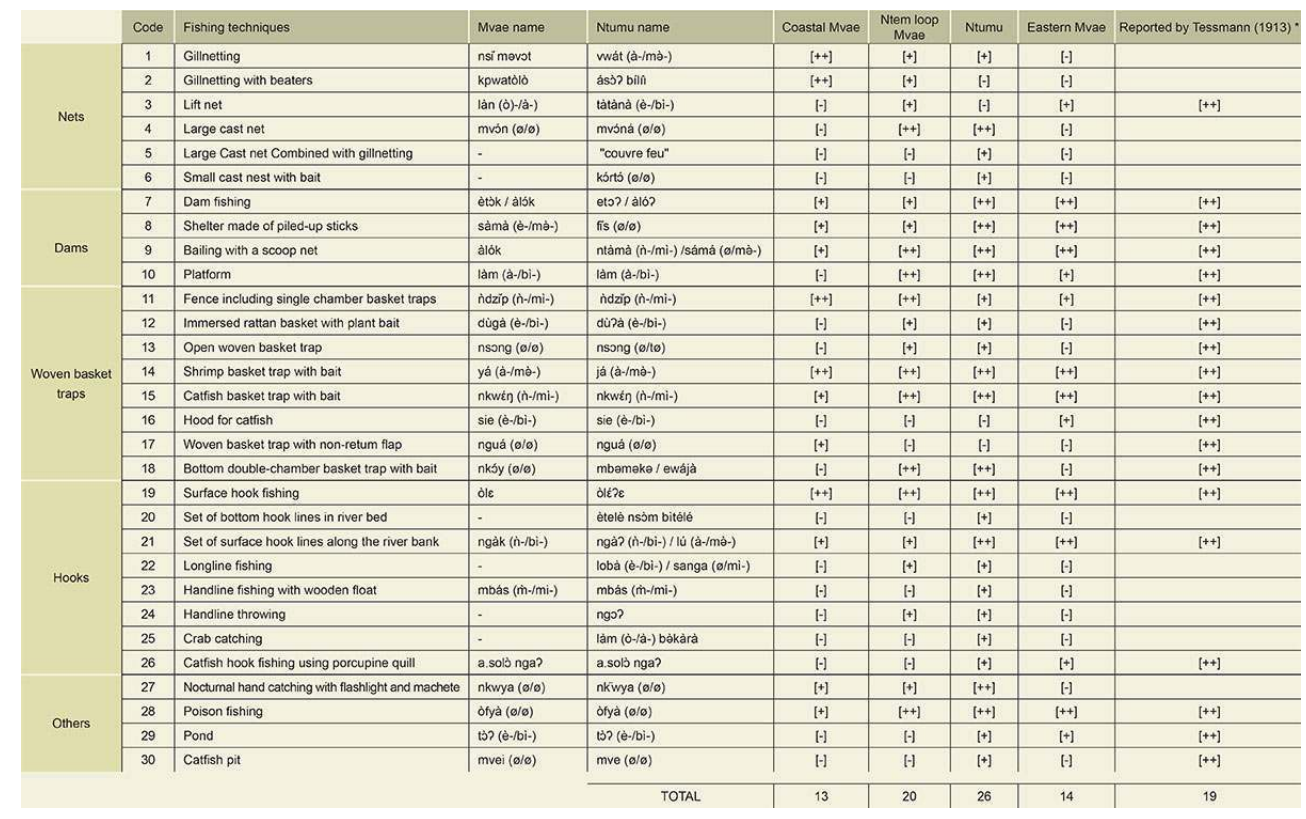

Use frequency: [++] regular; [+] rare; [-] non longer used; [blank] unknown

Total per ethnic group correspond to regular + rare practices

* Past methods reported by Günter Tessmann in 1913: no possible distinction between regular and rare uses, so regular is mentioned by default

This functional typology puts special emphasis on the water level that is understood by these ethnic groups as the most seasonally varying environmental parameter. It is in accordance with ichthyological science that puts forward the fundamental role of water level in the ecology and behavior of inland rainforest fish fauna in search for available habitats that are mediated by seasonal rains (Chapman 2001).

Taking optimal advantage of the watershed vascularization, the Mvae and Ntumu have acquired an extensive expertise in adjusting their fish capture modalities: diurnal versus nocturnal, permanent versus ephemeral, opportunistic versus controlled, masculine, feminine or mixed, adults versus children, solitary versus pairs, trinomial or groups capable of bringing together dozens of protagonists... From simple angling carried out individually to sophisticated dams and platforms that are built collectively, the fishers of the Ntem river have elaborated - and sometimes borrowed from other groups - a valuable diversity of fishing methods. But fish are not the sole resources captured during these activities: besides fish eggs, fry, big fish - with or without scales - the Ntem waters also provide countless mollusks, amphibians, reptiles and aquatic mammals.

Such plethoric availability should not however conceal the risks run by the fishers and the likelihood of unsuccessful fishing expeditions. More than for any other wild food procurement, fishing is an act that requires the willingness of the supernatural forces, most of which take up residence in rivers and exert a symbolic control over water resources (Pagezy \& Guargliardo 1992, Pagezy 2006, Plancke 2011, Comptour this issue). These forces are mostly active at night so nocturnal fishing activities increase the risks of disturbing and angering them. The overt recreational and enjoyable atmosphere that livens many fishing activities up is a way of warding off fears and averting threats. Throughout the tropics, sea, fluvial, and lake waters are believed to host all sort of monsters, unnamable creatures, and powerful divinities. Men-fish, sirens, Mami Wata ${ }^{2} \ldots$ 
are recurrent figures of the mythology of African rainforest peoples. There is no single founding myth that does not take its origins in the depths of a lake or a stream, in the brackish or unhealthy waters of mangroves, swamps or shallows, or in their epic crossing. When they penetrate in the water, forest inhabitants humbly measure their eminently fragile condition. Entering the water symbolically means a return to the primordial status of helpless fetal creature accessing to life in this aqueous environment that precedes birth.

\section{Fishing techniques using nets}

Before the advent of the synthetic fiber net that dates back to the middle of the twentieth century, fishing with nets was fairly anecdotal. Nets were made of vegetal fibers and were used collectively, in categories 1 and 2 watercourses, and only during the dry season to facilitate the drying of the fibers and thus maintaining their longevity. The nylon net of Chinese origin is an undeniable novelty in fishing activities throughout the African continent. Nevertheless, while it has become the almost exclusive tool of production for inshore fishermen, it has not revolutionized in similar proportions the inland wild fisheries. The rapid adoption of nylon net is essentially due to the resistance of synthetic fibers to prolonged soaking. Nevertheless, a gillnet is an expensive investment $(25,000$ FCFA) that is rarely affordable by those who fish only to satisfy their domestic consumption. Only those who commercialize a significant portion of their catches can afford to possess gillnets.

Fishers distinguish different net models by the size of mesh, which is calculated using the finger width as a standard measure unit: A large majority of Mvae and Ntumu gillnet fishers possess nets with a 2.5-finger sized mesh that serve for the capture of small to medium sized fish for domestic consumption; very few fishers have larger mesh nets (3.5 to 4 -finger sized) that are more adapted to the capture of large fish with scales for the market economy. The standard commercialized size of nylon net is $90 \mathrm{~m}$ long per $2 \mathrm{~m}$ wide. The fisher will split it into 3 or 4 shorter nets, according to their expected use.

\section{Fishing technique 1: Gillnetting}

Gillnetting ${ }^{3}$ is a solitary, male and mostly diurnal fishing activity. It is practiced on foot or from a canoe depending on the water level. It occurs preferably during the rainy season in small watercourses and flooded areas. Nets are stretched with stakes perpendicularly to the shore and are kept vertical and close to the surface by a combination of sinkers (stones, lead) and floats. Gillnetting is occasionally prolonged during the early dry season in larger watercourses of categories 1 and 2 watercourses and targets surface swimming fishes. The net is directly attached to the vegetation of the shore and is held at its other end by a weight, which prevents it from drifting.

A nocturnal version of gillnet fishing consists of stretching at night one, two or more nets in series across category 2 watercourses. Nocturnal gillnetting occurs mostly at the end of the dry season and ceases with the arrival of the first few rains. Fishes referred to by the local fishers as 'captains' (Barbus spp. ${ }^{4}$ ) and kos ékòp 'fish without scales' (mainly spotted Auchenoglanis spp. ndoo) move to the tributaries of the Ntem river for nocturnal feeding. They will swim back to the confluences a little before dawn. The nets are stretched late at night after that the fish have entered the tributaries, and they are removed in the early 
morning. The reason invoked for not continuing this activity during the rainy season is the heavy quantity of branches and logs that are loaded by strong currents and that may damage the nets. In that respect, the coastal Mvae consider the beginning of the small rainy season to be the optimal moment for gillnetting because it offers a fair compromise between the abundance of fish and the difficult conditions for net stretching. If well maintained and regularly repaired (Figure 6), gillnets can last about five years. Several hours must be devoted daily to untangling and restoring the broken stitches, to eliminate the plant residues blocked in the mesh and to put the net to dry. The late 1980s saw the advent of a new net nicknamed wàtà wàtà (pidgin of 'water water'). Although more expensive and short-lasting because it is not repairable (woven mesh are replaced by welded ones), this net is favored by fishermen because of its transparent color that makes it less visible by fish.

\section{Figure 6: Gillnetting}

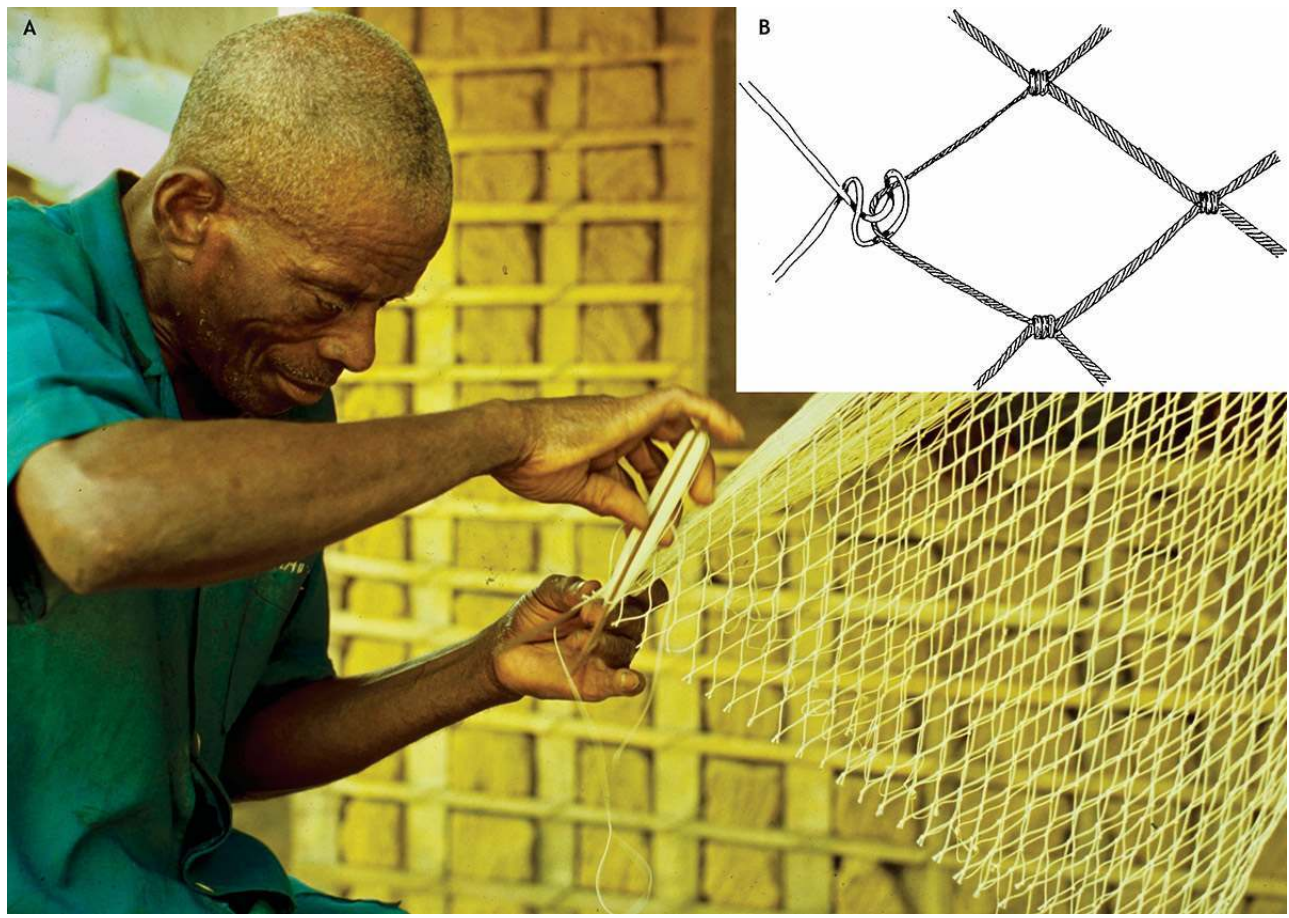

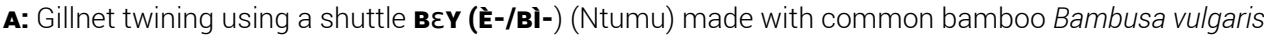

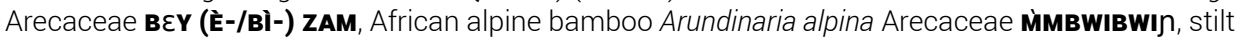
roots of Uapaca spp. Phyllanthaceae SÀM (À-/MÈ-), or wood of Monodora myristica Annonaceae MF́́n - B: Meshing detail MvuKuLu

(c) E. Dounias

\section{Fishing technique 2: Gillnetting with beaters}

During the dry season, several successive nets are stretched across the riverbed in the lower side of a category 2 watercourse. The watercourse is chosen for its transparent and low-level water ( $1 \mathrm{~m}$ deep in maximum) enabling to watch the movements of the schools

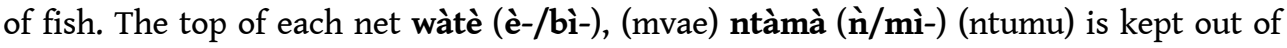
the water by stakes while the lower edge is weighted by stones mòngòk móvot.

Once the nets are in position, water beating àdjílí kwòs is initiated several hundred meters further upstream. The beating, performed by three or four protagonists, consists 
of vigorously whipping the water with a stick, in order to force the fish to escape further downstream. Children are posted as watchers a hundred meters above the nets and will alert the fisherman posted near his nets as soon as the schools of fish are near. When approaching the downstream nets, the beaters quickly stretch a closing net to prevent any retreat of the schools of fish back upstream. The vise is gradually closed and fish are pushed into the downstream nets.

This gillnetting variant requires the participation of at least five protagonists (one adult fisherman who is the owner of the nets, and a few youth or women assistants) and provides a lot of fish (Figure 7). However it imposes a long stay in the water and a solid physical commitment by each participant. Success is conditioned by the respect of a cultural prescription that is to avoid complaining about the cold and humidity during the whole activity. The Ntumu use scoop nets tàn ( $\varnothing /$ mè-) (see fishing technique $n^{\circ} 9$ below) instead of gillnets and name this fishing method ásò? bílîi (ásò? 'to frighten', álíi 'to stay').

Figure 7: Gillnetting with beaters (Mvae)

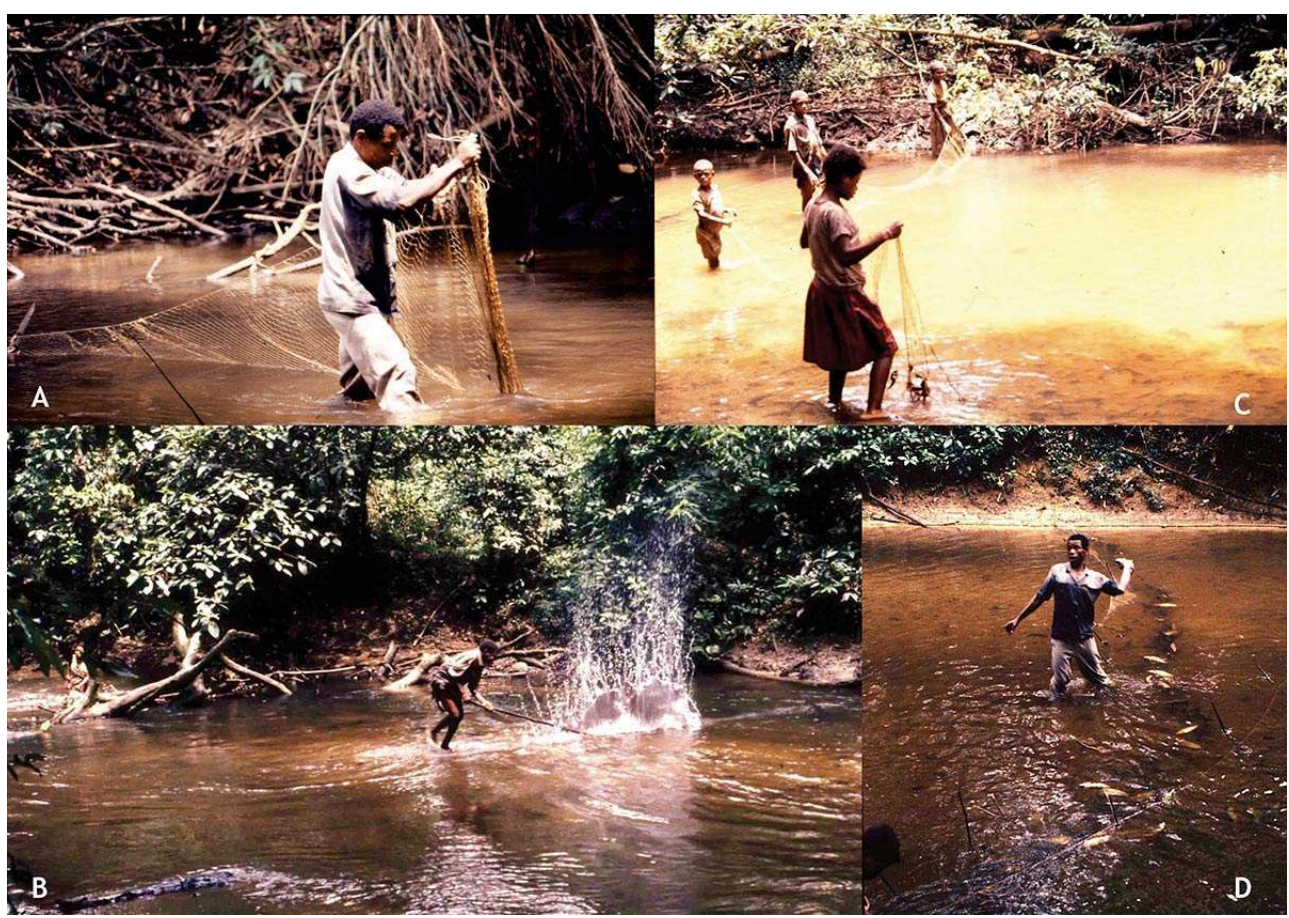

A: Installation of floating gillnets downriver - B: Beater in action upriver - c: Avoiding schools of fish from returning upriver $-\mathbf{D}$ : Extracting fish from downriver gillnets

(c) E. Dounias

\section{Fishing technique 3: Lift net}

Lift net fishing consists in obliquely immersing a large circular sieve with loose mesh and rattan frame, which the fisherman maneuvers like a harrow. The sieve pivots around an emerging fixed support and is set perpendicularly to the current, its base touching the bottom of the riverbed. The fisherman is seated on a scaffolding built above the water. When he perceives a contact between a fish and the net, he hoists the net by pulling up a rod fixed at the base of the sieve (Figure 8). The lift net mesh is woven with vegetable 
fibers called òkòy, a generic term that federates fiber producing plants like Clappertonia polyandra (Tiliaceae), Triumfetta cordifolia (Tiliaceae), achiote Bixa orellana (Bixaceae), and the Congo jute Urena lobata (Malvaceae) more specifically called òkòy bəkwi ('fiber plant of the Pygmies') by the Mvae.

Lift net fishing is reserved to well-trained adult fishermen. These nets are solely set up in category 2 streams with moderate water flow. Lift net fishing takes place preferably during moonless nights, but also during daylight right after a heavy rain that has increased the turbidity of the water, thus favoring the discretion of the fishermen. Ntumu elderly fishers, who have no longer practiced this fishing methods for a long time, evoke a collective activity involving water beaters who pushed the fish down to the net (Cogels 2002).

Figure 8: Lift net fishing: persisting modalities (Mvae)

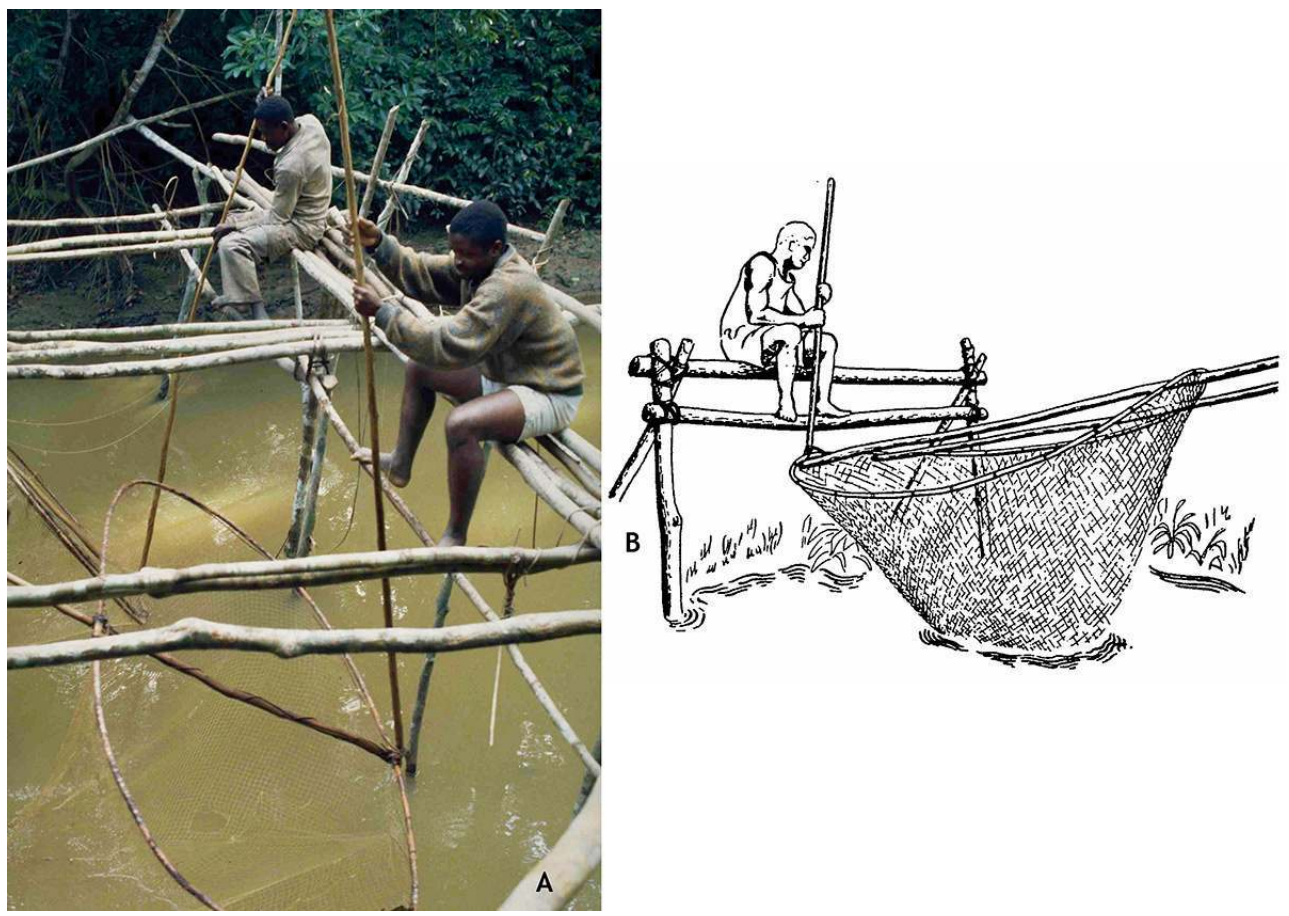

A: As observed by Edmond Dounias in 1996 (c) Edmond Dounias - B: As depicted by Augusto Panyella in 1959

\section{Fishing technique 4: Large cast nest}

Before the advent of nylon, cast nests were made with fibers of cyغ̀m $\varepsilon$ (è-/mì-) Euphorbia sp., Euphorbiaceae or òkòy (see fishing technique $\mathrm{n}^{\circ} 3$ ). Modern cast nests are made of 2 to 3-finger sized mesh net and their span can reach $13 \mathrm{~m}$. It is an eclectic male fishing method that is however confined in the Ntem loop. Cast nests can be thrown on foot in shallow waters - where the fishermen carefully observe the buccal traces imprinted by musophagous fish mbèrò ( deeper waters. But cast nests are also efficient in rapids and in strong current areas ̀̀ndón especially in January (Figure 9). This broad range of water types allows a practice of cast nests any time during the year. 
ast nest fishing is a daytime and nighttime activity. When carried out at night, it is often combined with flashlight and machete explorations (see fishing technique $n^{\circ} 27$ ). Diurnal and nocturnal catches differ substantially: diurnal cast nest fishers in rapids during the dry season seize Distichodus, Tilapia, Barbus, Phenacogrammus, Alestes, and Phractura species; nocturnal expeditions during the same season mainly capture Labeo and Chiloglanis species.

Figure 9: Cast nest fishing in the Ntem loop (Ntumu)

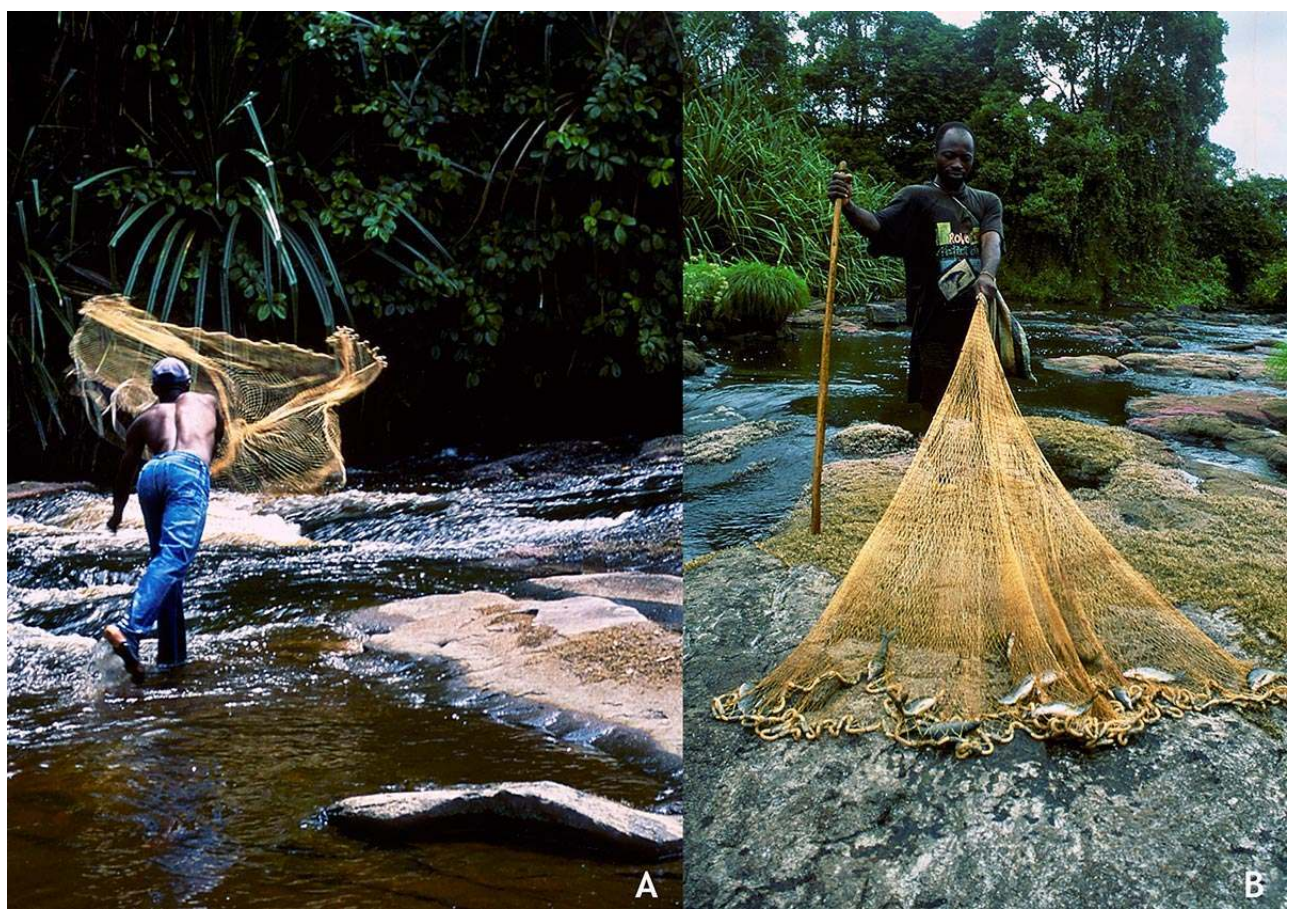

A: Cast nest throwing - B: Fish captured in the cast nest

(C) IRD / S. Carrière

\section{Fishing technique 5: Large cast nest combined with gillnetting}

31 The Mvae and the Ntumu fishermen who live in the Ntem loop carry out a peculiar form of nocturnal cast nest fishing. It takes place in sizable deep water pools formed during the dry season in little branches of the river after that the water has receded. This collective and male activity combines gillnets and cast nests and is misleadingly termed 'couvre feu' (curfew) in local French. In fact the metaphor more appropriately refers to 'contre feu' (backfire): cast nest throwing is a means to divert the schools of fish and to push them into gillnets. Depending on the water depth in the pool, fishermen progress on foot or in canoes.

\section{Fishing technique 6: Small cast nest with bait}

32 A smaller model of cast nest with smaller mesh (1.5 to 2-finger sized mesh) is handled daytime in spawning areas èbé dó?. Two periods are mostly appropriate for its use: January when Cyprinidae fishes come and lay their eggs near the rapids of the Ntem river arms; September when various species of fishes spawn in category 3 streams. The use of 
this cast nest is generally associated with baits - crushed palm nuts, pieces of termite mounds - that are poured on the nesting areas. This fishing method is restricted to the Ntem loop area and is not known by the coastal and eastern Mvae groups.

\section{Fishing techniques using dams}

\section{Fishing technique 7: Dam fishing}

This diurnal fishing method that is held during the dry season is feminine par excellence and is by no means carried out exclusively by the Mvae and Ntumu: a detailed description of dam fishing by the Baka women of eastern Cameroon is provided by Gallois and Duda (this issue). Dam fishing takes place in category 3 streams and category 4 flooded lowlands that are refuges for shellfish and mudfish such as Clarias camerunensis. Branching streams mèkánán mómbâ are chosen as favorable starting points for dam fishing because, after building a dam my\&k (generic term for dam) at the entry of the stream to explore, the water can continue flowing down in the unclosed arm. The upstream dam, called ǹnóm apo for this specific fishing activity, is the most important: its solidity will condition the length of the fishing expedition, which can last several hours and which is generally stopped when the upstream dam is broken or overflowed.

Wooden sleepers are pilled up horizontally against vertical stakes zùm that are held by oblique forks àtak. Women fill the gaps with packets of leaves mvwín and aquatic herbaceous plants like Brillantaisia sp. Acanthaceae èbuk boy. The dam is finally sealed by sludge àdzía transported in kitchen containers or scoop nets (see Figure 12). Sometimes, women make a chain to pass the filled containers.

Secondary dams ngá ajo are built further downstream to delineate successive pools tók (è-/bì-). Stakes and forks are not used for these less solid secondary dams that are intended to hold just the time of scooping. The size of the successive pools varies from 20 to 50 square meters. Bailing out the water of the temporary pool is the most constraining part of this fishing activity (Figure 10). All the participants take part in this task that is punctuated by enthusiastic songs, shouts and gossips. In the past, water was bailed out using wooden discs kànà (è-/bì-) (see picture B of Figure 10) carved out of a buttress of Ceiba pentandra, Bombacaceae dùm (ø/ø). This wood was chosen for its tenderness, lightness and resistance to water. Metal and plastic kitchen utensils have now replaced this disc. Once the major amount of water is bailed out, participants divide into different task groups: adult women start exploring the mud and natural anfractuosities in search for catfish and shellfish, while young girls pursue scooping further downstream.

The exploration of cavities under tree roots bìbàn 'houses of the fish' and burrows extending under the banks is apprehended by many women, because of the risks to be painfully stung by the defensive spines along dorsal and pectoral fins of many Clariidae, shocked by an electric catfish, bitten by a dwarf crocodile, a giant otter shrew, or a venomous aquatic cobra. The heckling that accompanies these fishing expeditions is a way to acquire courage and energy, to evacuate fear and stress, and to encourage unwished and dangerous animals to escape.

37 The residual water of the pool is channeled through scoop nets that are held vertically to stop the small fish that are caught manually. Other preys like crabs, electric fish and fishes that hold spiny fins are killed with a machete. Besides Clariidae fishes and shellfish 
that are captured in great quantities, the other prominent catches are Pollimyrus kingsleya e, Marcusenius moorii, Citharichtys stampflii, Auchenoglanis spp., and Hemichromis fasciatus. For final sharing àkàp, fish are divided into heaps of equivalent size, taking into account fish sizes but not species. Heaps are then distributed equally among households. The individual is the share unit for large fishes and crabs (two small crabs are equivalent to a large one); A cup bwàn bə̄ kwòs is the measure unit for sharing small fry and shrimps.

Figure 10: Dam fishing in an affluent of the Ntem river (Ntumu)

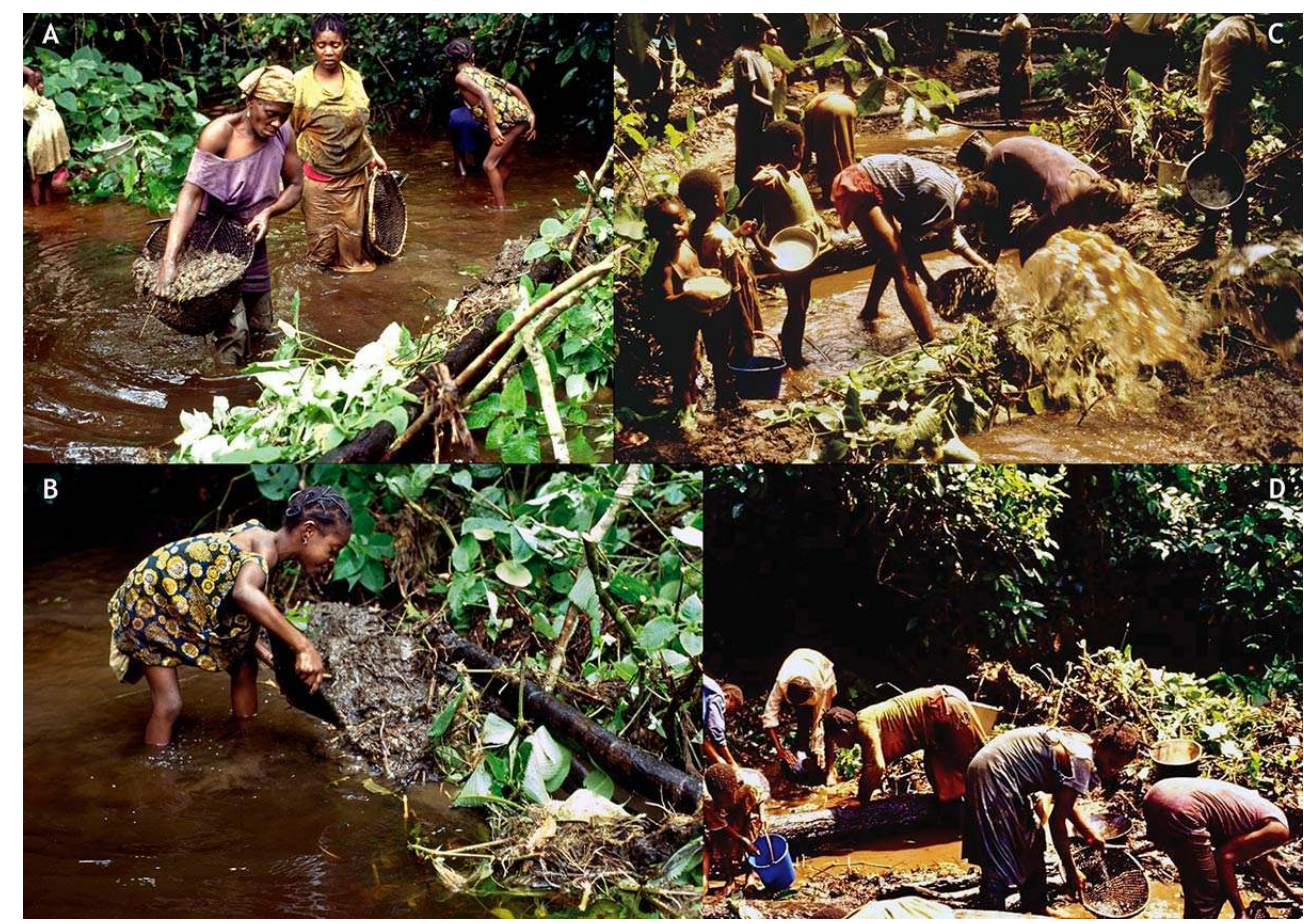

A: Dam building and consolidating (mud carried in a scoop net) - B: Dam sealing with mud carried in a wooden bailer KÀNÀ (⿳亠丷厂犬-/Bì-) - C: Water scooping - D: Capturing fish with a scoop net TÀN (ø-/MÈ-) (c) E. Dounias

\section{Fishing technique 8: Shelters made of piled-up sticks}

This female fishing activity, which is carried out in pairs or in trios (often a mother and her daughters) consists primarily in building an artificial shelter over a 10 to 20-squaremeter surface. Women choose shaded curves of category 2 watercourses tón (ò-/à-) to set up their shelters. A shelter is composed of piled-up wooden sticks, which are covered with shading palms of Raphia spp. While the Ntumu evoke the piled-up sticks fis to name this fishing method, the Mvae rather term it with the name of Raiamas buchholzi, Cyprinidae sàmà (è-/mè -), the fish that is most commonly attracted by these artificial shelters when it migrates further upstream in search for convenient spawning areas.

During their weekly visit of the shelter, the participants firstly divert the flow of water by erecting a mound of sludge mixed with plant debris, like a dam surrounding the shelter. The piled-up sticks are then removed, starting downstream and progressively further upstream. While assistants scoop out the residual water, the owner of the shelter retains the fish with her scoop net, as already described above for dam fishing (see fishing 
technique fishing technique $n^{\circ} 7$ ). At the end of the fishing session that may take up to 3 hours, the shelter is carefully piled-up again and the dam is broken for further visits.

The catches are always small size fishes that are however highly appreciated for the taste: Microsynodontis batesi, Marcusenius spp., Petrocephalus sp., Pollimyrus kingsleyae, various Cyprinodontidae and, last but not the least, Raiamas buchholzi: although they are renowned as heavy bushmeat eaters (Dounias 2016), the Mvae rank this ray-finned fish at the forefront of their food preferences. This reveals the importance attached to this fishing method, which can be assimilated to a pseudo-domestication: shelters are owned by the women who built them, and their dismantling in order to catch the fish cannot be made in the absence of the owner or without her prior consent. Such artificial watercourse arrangements that modify natural habitat to attract fish are reported in many other parts of equatorial Africa (Harms 1999, Gabriel et al. 2008).

Figure 11: Shelters made of piled-up sticks (Mvae)

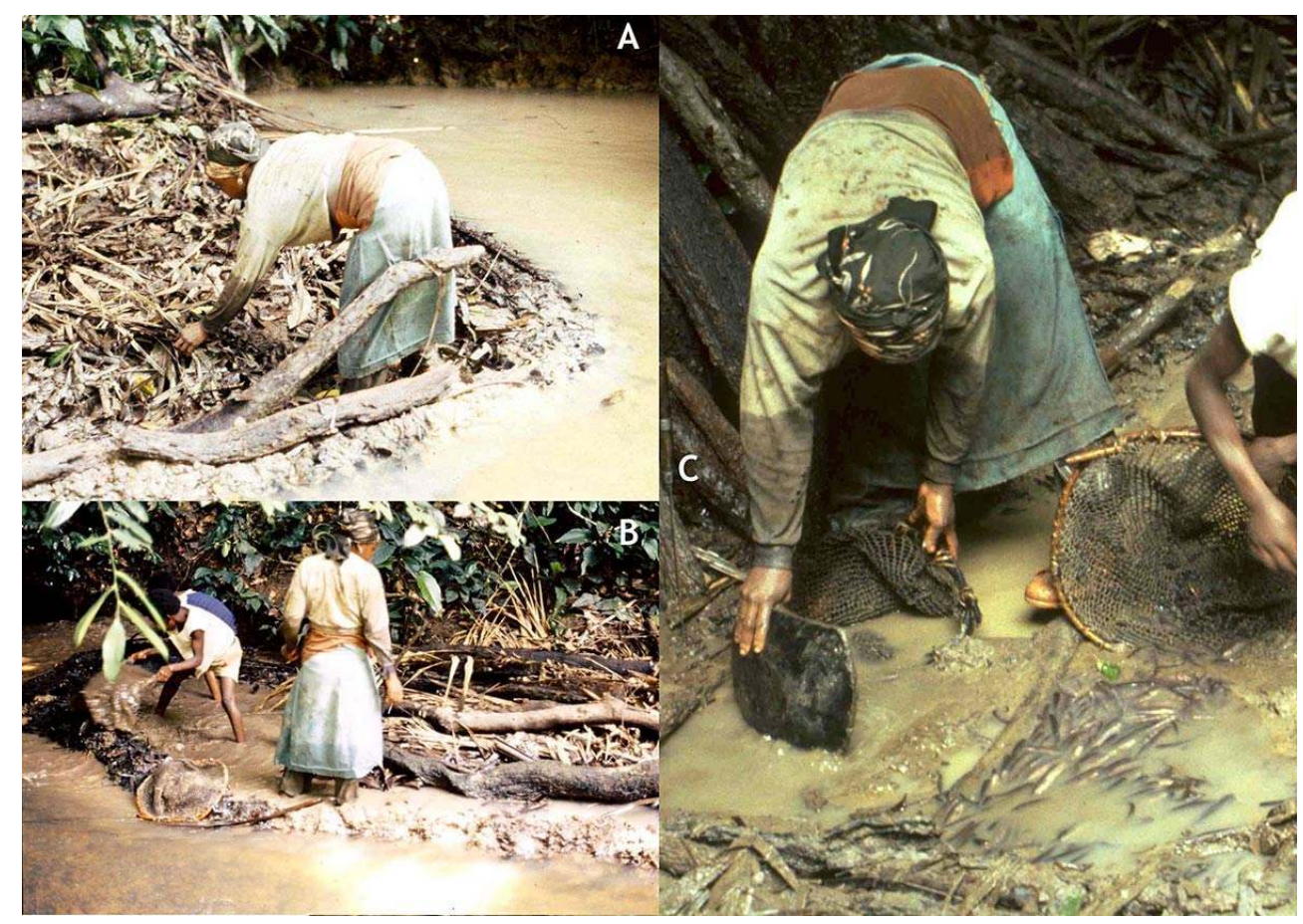

A: Removal of leaf and piled-up sticks - B: Water scooping - c: Fish capture using a wooden bailer and a scoop net

(c) E. Dounias

\section{Fishing technique 9: Bailing with a scoop net}

The scoop net is a fishing tool whose specific shape is typical of the Fang-language speaking groups (Figure 12). It is called tàn, a term that shares the same semantic origin with ètàtànà, the lift net. The circled body of the scoop net consists of a stem of Hypselodelphys scandens, Marantaceae nkòmònkómó and the loose mesh of the sieve is made of òkòy fibers (see fishing technique $n^{\circ} 3$ ). Mvae women implement scoop net fishing in category 4 low-level $(20 \mathrm{~cm}$ deep) and stagnant waters. After having closed the upper part of the waterway with a mound of mud or silt, they stand in pairs or trios next to each other and, starting from downstream, progress altogether further upstream. 
Women bend forward and hold their scoop nets vertically and perpendicularly to the water flow. They store their catches - taken by hand or killed with a machete - in a small basket ǹnkún made with stems of ndèn Megaphrynium macrostachyum Marantaceae and attached to their waist. Most common catches are Bagridae (Auchenoglanis spp., Chrysichtys spp. and Parauchenoglanis spp.), Cichlidae (Nannochromis spp.), Cyprinodontidae (Aphyosemion) and, most abundantly, Mormyridae juveniles (Marcusenius spp.). Ntumu women of the Ntem loop implement this fishing activity when the water is very low (respectively February and August) in a branch tributary of the Ntem loop that is previously closed by a dam.

Figure 12: Bailing with a scoop net (Mvae and Ntumu)

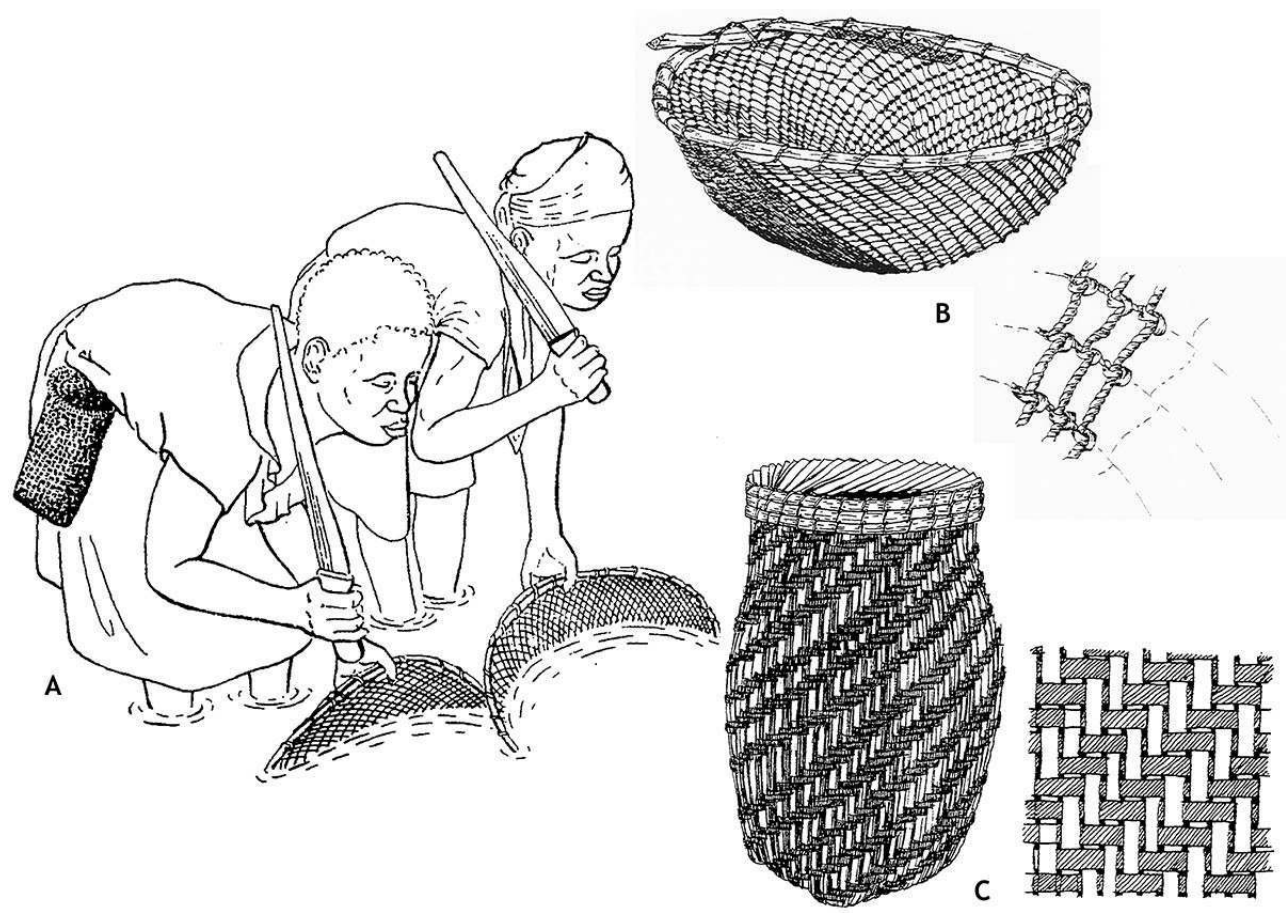

A: Scoop net use as depicted by Panyella in 1959 - B: Detail of the scoop net and meshing - c: Detail of the hip basket and weaving

(c) E. Dounias

\section{Fishing technique 10: Platform}

This structure is installed by a group of several fishermen in a category 3 watercourse, before the end of the dry season and when the stream is dried up. A solid dam is built: it consists of vertical wooden stakes that are held by oblique forks. Heavy pebbles nda mòko? increase the weight of the dam structure and make it more resistant to water flow. Palms of Raphia sp. (Asteraceae) are added for waterproofing. A platform àkày is installed in the middle of the dam. It is oriented downstream and its extremity is heightened so to emerge from the water flow. The floor of the platform is made of disjointed bamboo slats, rachis of Raphia palms, or large-diameter canes of rattan ngàm (ò-/à-) Laccosperma secundiflorum, Arecaceae, that are interwoven with rattan ropes. The building of the whole structure takes about 3 weeks. During the rainy season, the water flow is stopped by the dam and is by-passed and accelerated into the funnel. The water 
flows across the interstices of the platform floor, and interstices are wide enough for small fish to pass through as well. The heightened end of the platform can be extended if the water level continues to rise. Large fish, predominantly of the Alestidae family, are projected on the emerging end of the platform by the strength of the current. The platform is in use continuously, daytime and nighttime, throughout the season of high water level. Large snakes (Python sebae, Naja annulata) are occasionally found stuck against the dam by the strength of the current.

Figure 13: Platform (Ntumu)

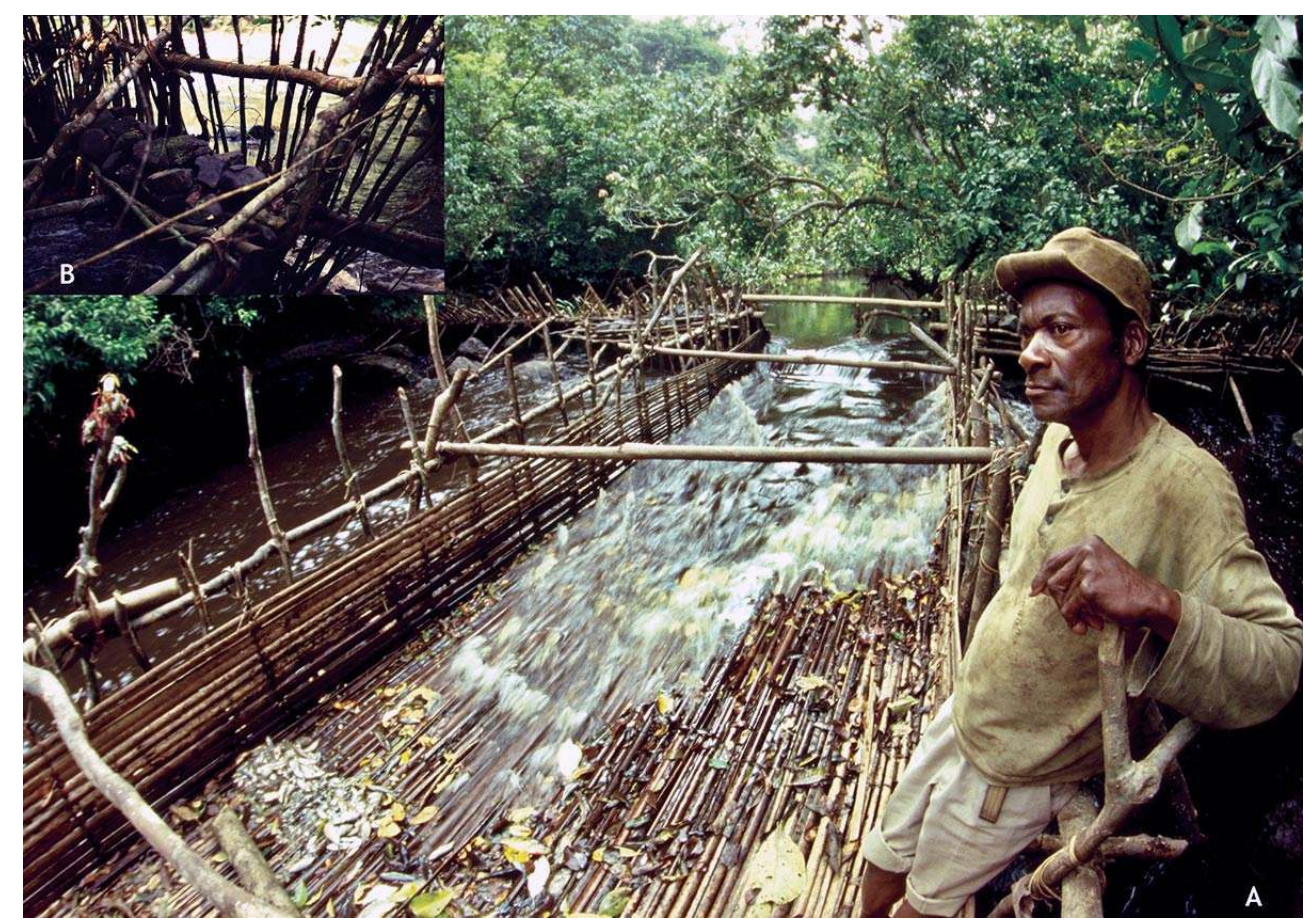

A: Fully functional platform during the rainy season - B: Dam building during the dry season (c) E. Dounias

\section{Fishing techniques using woven basket traps}

\section{Fishing technique 11: Fence including single-chamber basket traps}

43 This structure is named ndzíp and is implemented at the beginning of the rainy season when the fish migrate upstream to reach their spawning areas in category 3 streams and category 4 seasonally flooded areas. It is interrupted in the middle of the rainy season, when the river loads too many plant debris that can damage the woven basket traps. This fishing activity is reactivated during low-flow periods of the dry season, when the fish have left their spawning areas and the water has receded. The activity is then called ndzíp nkót.

The first step consists in building a watertight fence made of a solid wood frame. Clogging is provided by clay soil and aquatic vegetation and the fence is consolidated with heavy pebbles. Openings are provided to channel the flow of water across single-chamber woven basket traps. Their conic inlets are oriented downstream. This installation requires shallow water streams with clear waters in order to follow the fish movement. 
During the dry season, the basket traps are installed before sunset and catch the fish moving upstream in search for food at night. The opening of the baskets trap is then the only possible way of passage. The basket traps are checked at dawn and removed until the following evening to allow free circulation of fish during the day. Clarias camerunensis, Hepsetus odoe, Brycinus tessmannii, Phenacogrammus uretonia, and shrimps are the most common preys.

This fishing technique differs for the Mvae and the Ntumu of the Ntem loop. It is for them a family activity that involves all the members of the household and it is performed during the dry season of July-August, taking advantage of the school holidays. The originality of the Ntem loop area is that beaters will push the fish to the traps. The beating is implemented from downstream and the beaters progress counter-flow: the reason is to prevent the traps from being clogged by the plant debris that are released by the beating. Like during gillnetting with beaters (fishing technique $n^{\circ} 2$ ), the beaters quickly stretch a closing net when approaching the fence, to prevent any retreat of the schools of fish back downstream. The fish are pushed to move further upstream and finally enter the traps. Most observed catches are fishes from the Characidae family ( Alestes barezome, A. tesmannii, Micralestes occidentalis, Brycinus tessmannii), a few Cichlidae ( Hemichromis spp., Leptotilapia sp., Pelmatochromis spp., Saroterodon mvogoi, Tilapia nyongana) and some Cyprinidae (Barilius spp.)

Figure 14: Fence including single-chamber woven basket traps (Ntumu)

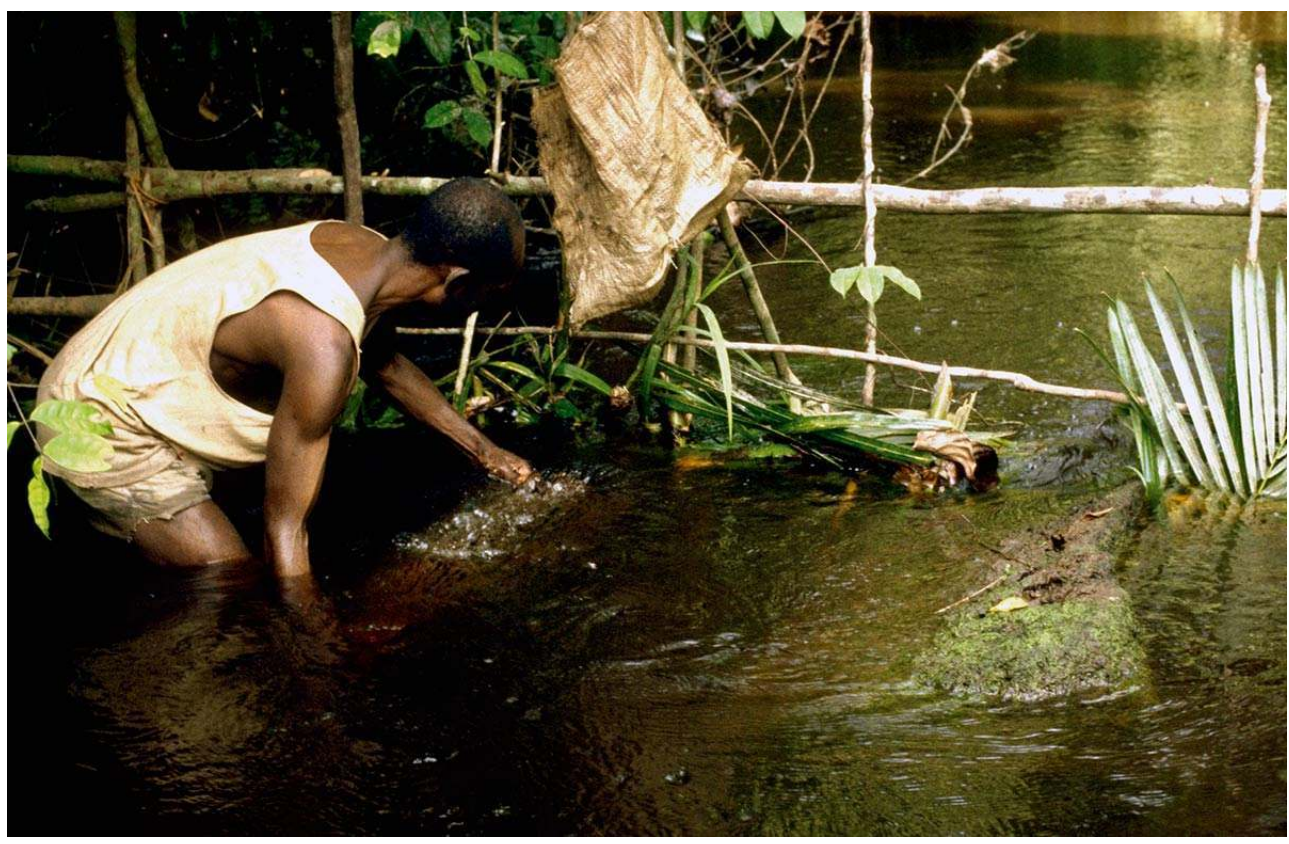

(c) S. Bahuchet

\section{Fishing technique 12: Immersed rattan baskets with plant baits}

Fishing with immersed rattan baskets is a nocturnal and collective fishing that is documented by Tessmann under the term làm (⿳亠丷⿵冂-/à-). It has since then fallen into disuse. dùgà (è-/bì-) are large baskets that were immersed in category 2 watercourses. Sometimes these baskets were installed in association with fences and single-chamber woven basket traps (see fishing technique $n^{\circ} 11$ ). The baskets were filled with baits àbì: 
rhizomes of ndòy Aframomum melegata, Zingiberaceae, barks of ngbade Cleistanthus angolensis, Euphorbiaceae, ònómókōk Milletia thonningii, Fabaceae, àmvìm Oxystigma bucholzii, Caesalpiniaceae, àsám Uapaca spp., Phyllanthaceae, leaves of èjes or èlók á kwòs Impatiens sp., Balsaminaceae, òbá ádzòm Renealmia congensis, Zingiberaceae, pieces of cassava tubers and sòn (è-/bì-) ants Crematogaster spp., Formicidae... The handling of these baskets required several participants, of all ages and both genders. Most common catches were shellfish and ǹntotòm Pollimyrus kingleyae, Mormyridae.

\section{Fishing technique 13: Open woven basket trap}

Unlike all the other woven basket traps, the oblong basket trap nsong (ø/ø) has no closing system cap ensuring that the fish that has penetrated into the trap can no longer swim out. The long body is made with rattan ngàm (ò-/à-) Laccosperma secundiflorum, Arecaceae and ties are rachis of Megaphrynium macrostachyum, Marantaceae ndغ̀y (ø/ø). This woven basket trap is positioned in the rapids ìndon, with its entrance oriented upstream. The strength of the current maintains inside the trap the fish that cannot swim back up to the entrance of this $2.5 \mathrm{~m}$ long trap. Sometimes the fishermen pile stones in the bed of the course. This elevation positioned just before the trap inlet artificially accelerates the flow of the current. The open woven basket trap catches fish that the Mvae and Ntumu group together under the name kwos masum 'fish without scales' and referring to fishes of Bagridae and Mochokidae families, which are characterized by strong defensive spines along their dorsal and pectoral fins.

This ancient fishing technique has now fallen into disuse. It is still in practice in the very remote areas of the Ntem watershed, especially by the Fang-Ntumu in northern Equatorial Guinea. Tessmann mentions its combined use in the rainy season with doublechamber woven basket traps nkóy (see fishing technique nº 18 below). 
Figure 15: Open woven basket trap (Fang Ntumu)

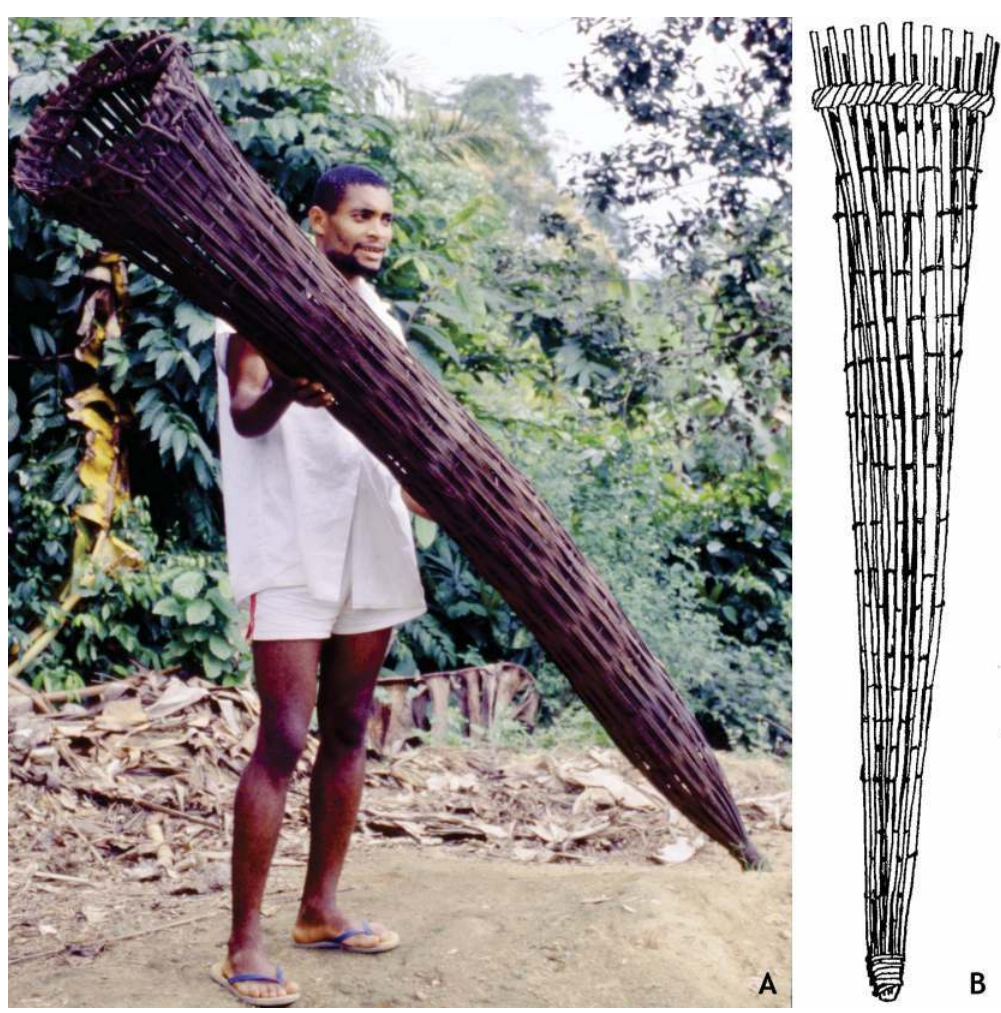

A: As still used by the Fang Ntumu in Equatorial Guinea ( E. Dounias - B: As depicted by Tessmann in 1913

\section{Fishing technique 14: Shrimp basket trap with bait}

The Mvae women of the coastal region are experts in capturing shrimps and other shellfish. For that purpose, they use small woven basket traps yá (à-/mè-). These basket traps are $35-40 \mathrm{~cm}$ long and are composed of a single chamber. They are made of rattan, and the cap is an inverted cone èdzìnà whose opening hole is oriented inwards. The fish can easily swim inside but cannot find their way back out. These basket traps are baited mainly with pieces of steamed cassava or residues of crushed palm nuts. Few women know out to make their own basket traps, and most of them order traps from men. These basket traps must be renewed every two or three dry seasons depending on the intensity of use. They are installed at dusk in the deep ètó $\mathbf{l}$ and shaded èzìnzìn waters of category 2 watercourses, which are excellent nesting sites. They are raised at dawn. Women mostly catch shrimps and crabs, and more rarely small fish such as juveniles of Mormyridae. This fishery is practiced throughout the year, with a preference for the dry season. In the rainy season, women are concerned about brutal floods that can sweep their basket traps away, so they resettle them in category 3 small streams, provided that the water of the chosen spots must be clear and clean.

The Mvae and Ntumu men and women of the Ntem loop used these woven basket traps in a different manner. They associated them with the oblong open basket trap (see fishing technique $n^{\circ} 13$ above) in a small flooded stream of category 3 watercourses. This combination gave rise to the erection of a mixed dam: the oblong open basket traps were positioned in the middle of the stream bed where the current is maximum, while the 
other basket traps were fixed near the edges with the opening side oriented downstream. Besides shrimps and crabs, small basket traps also caught fishes like Clarias camerunensis, Hepsetus odoë, Brycinus tessmannii, and Phenacogrammus uretonia.

Figure 16: Shrimp basket traps with bait (Mvae)
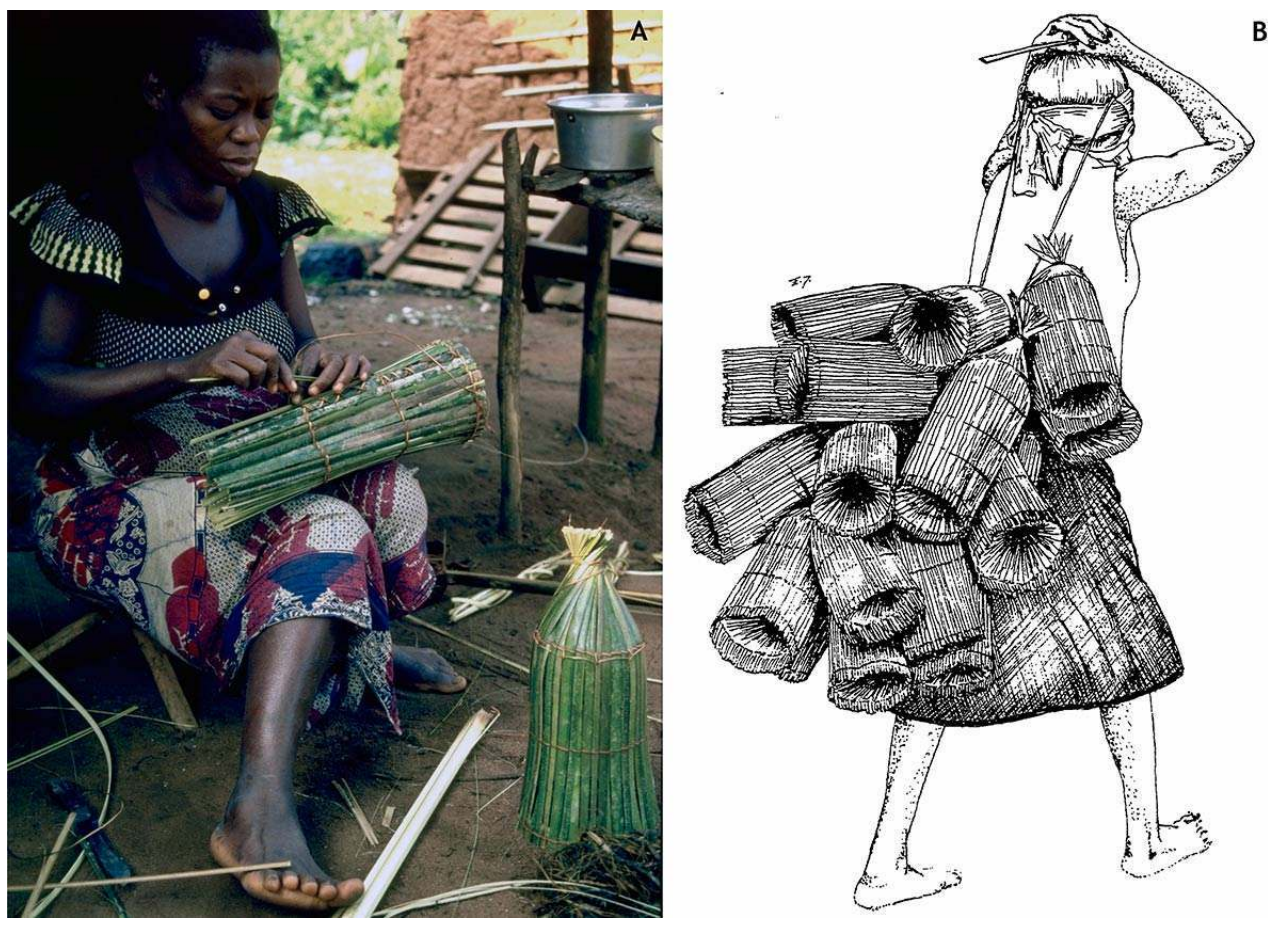

A: Woven basket trap making using rattan material @ S. Bahuchet - B: Depiction of a woman carrying her woven basket traps (c) E. Dounias

\section{Fishing technique 15: Catfish basket trap with bait}

51 These woven basket traps called nkwÉn are shaped like the shrimp basket traps (see fishing technique $n^{\circ} 14$ above) but are much larger and longer (120 to $150 \mathrm{~cm}$ ). They are manufactured and used by male fishers who install them during the dry season in the stagnant waters of swampy areas bìnón but also in the muddy arms lóp (è-/bi-) of categories 1 and 2 rivers, or in isolated stagnant pools bárá? (è-/bì-) formed after that the seasonal flood waters have receded. Catfish are attracted inside these basket traps by baits composed of steam-cooked cassava pieces or residues of crushed palm nuts. 
Figure 17: Catfish basket trap with bait

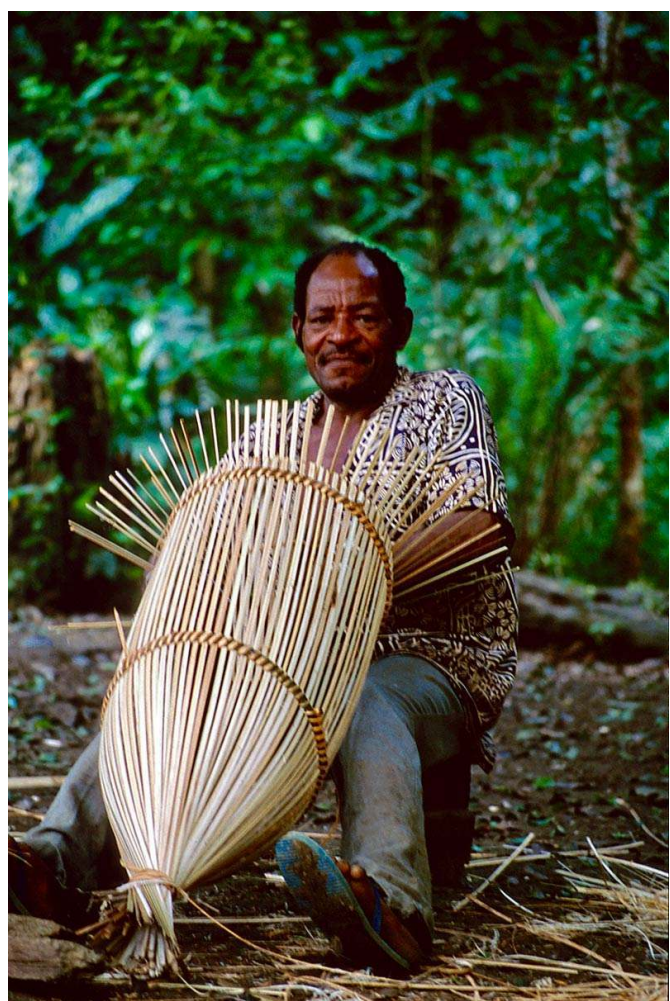

(c) S. Carrière

\section{Fishing technique 16: Hood for catfish}

Outlined by Tessmann as a variant of the immersed basket dùgà (è-/bì-) described above (see fishing technique $\mathrm{n}^{\circ} 12$ ), the hood sie (è-/bì-) was much larger ( 3 to $4 \mathrm{~m}$ wide, $1.5 \mathrm{~m}$ high) and a cap was set before pulling it out of the water. The handling of such bulky and heavy hoods required a lot of protagonists and was cumbersome, thus explaining their progressive neglect. The basket was baited like the dùgà (è-/bì-) basket, but could trap larger size catfishes of the Bagridae family.

\section{Fishing technique 17: Woven basket trap with non-return flap}

53 The woven basket trap with non-return flap ngùa is an old fishing technique that is reported by Tessmann. It is a male and adult activity and it targets Clarias camerunensis catfish. Coastal Mvae children - and their Yasa inshore fisherman neighbors alike (Bahuchet 1992) - use a very similar trap to catch the African rainbow crab kara (ø/bè-) Cardisoma armatum, Gecharcinidae, on the estuarine banks. In both cases, traps are baited with smashed palm nuts. 

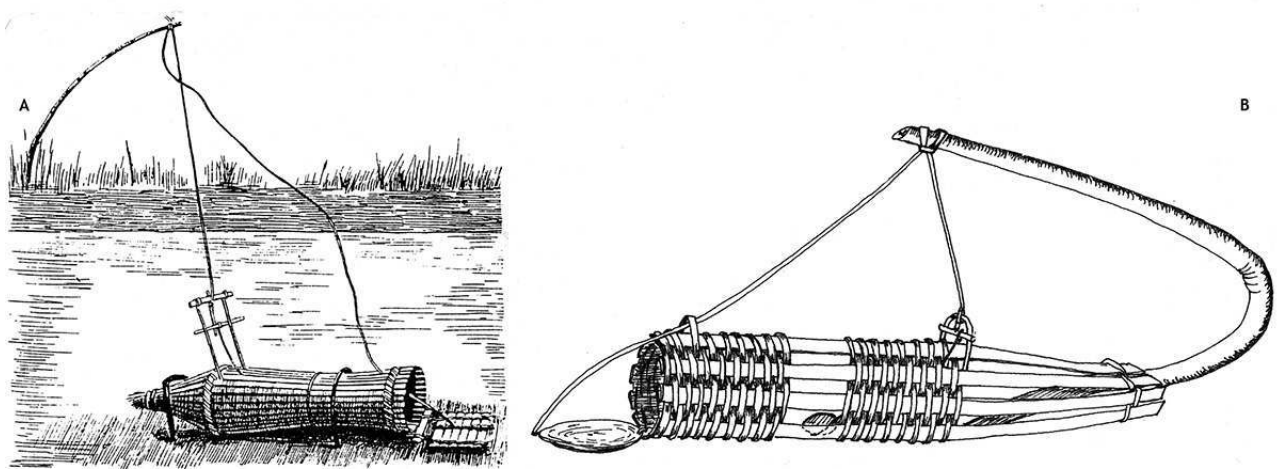

A: As depicted by Günter Tessmann in 1913 - B: As depicted by Edmond Dounias in 1993

\section{Fishing technique 18: Bottom double-chamber basket trap with bait}

The use of these woven basket traps is a diurnal male and individual activity, carried out in the major rivers during the dry season, when the current is moderate. These basket traps are made of rattan and are $1.5 \mathrm{~m}$ long. The cap is an inverted cone whose opening hole is oriented inwards. But their singularity resides in their two compartments and their handling requires a canoe. They lay on the sandy bottom in calm, deep and shady waters èzìnzìn - under the foliage of Uapaca trees but especially of the deep banks invaded by aquatic herbaceous plants like Brillantaisia sp., Acanthaceae and Impatiens sp., Balsaminaceae.

The baits consist of pieces of cassava briefly steam cooked àkpwà məmbòy and palm nuts pounded but still firm in order to support several successive immersions. Other baits are possible: cassava leaves, Aframomum citratus, Zingiberaceae leaves àdzòm and game viscera. The bait is stored in the second chamber. Much of the trapped fish will remain in the first chmaber. This separation between bait and prey is a hint for not having to renew the bait too often. The trap is attached to the bank (roots stilts for example) by a solid rope of rattan. Under the effect of the weak current or the slope, the net sometimes derives from its anchorage point. The traps patrolling takes place every 2 or 3 days: the fisherman unties the rope at the point of attachment, then slowly pulls up the trap to the surface. He pours the contents into the canoe after opening the conical top. He then puts the bait back into the second chmaber, closes the trap and plunges it back into the water. The Bagridae Auchenoglanis guirali, spotted catfish and without scales, constitutes the main catches (Figure 19). 
Figure 19: Bottom double-chamber basket trap with bait (Ntumu)

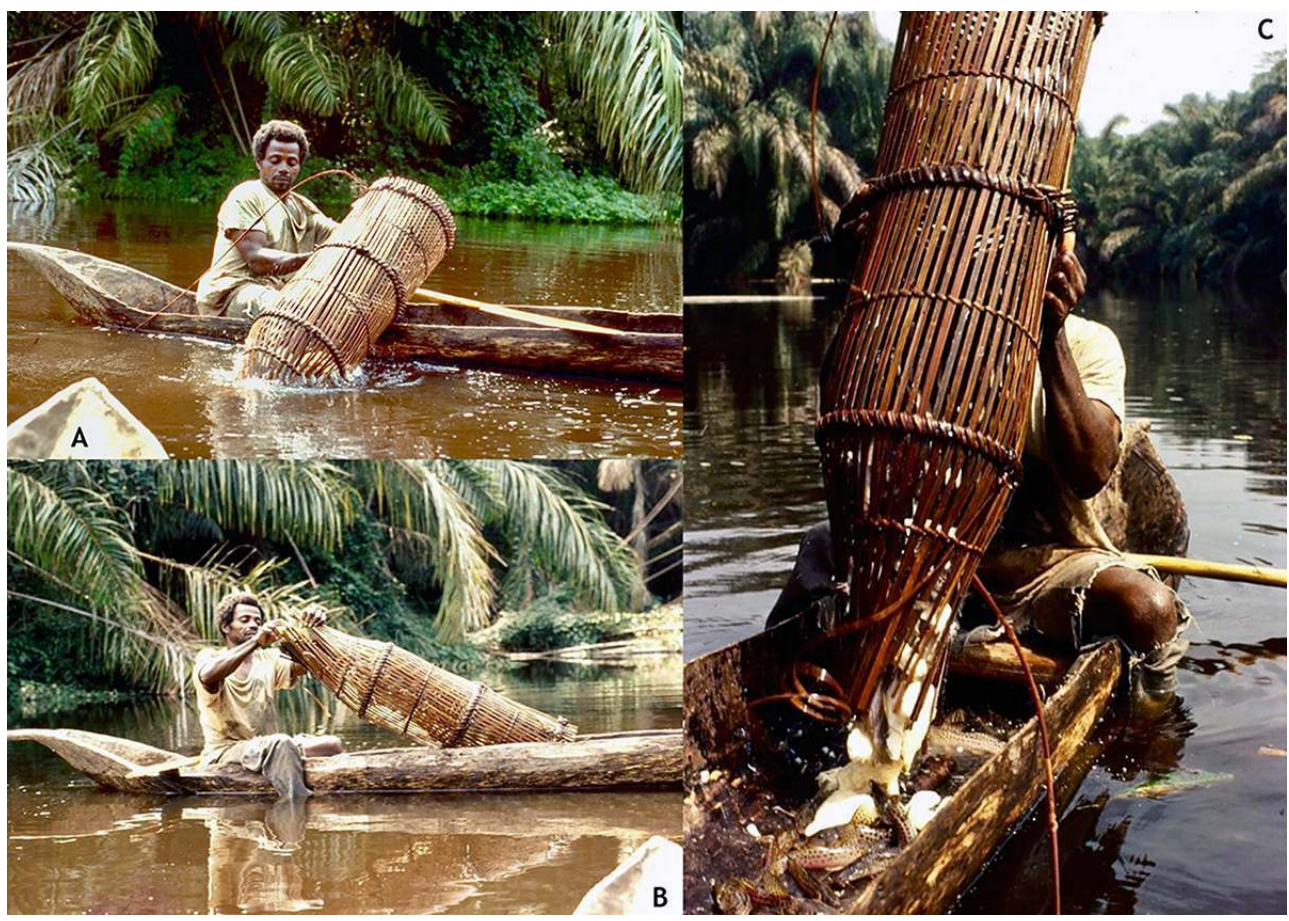

A: Hauling the basket trap to surface - B: Opening of the basket trap - c: The contents of the basket trap - pieces of cooked cassava tubers as baits and captured claroteid catfish Auchenoglanis guirali, Bagridae - are shaked out into the canoe

(C) E. Dounias

\section{Fishing techniques using hooks}

The use of line and hooks is long-standing, but anecdotal as long as fishermen had no choice but using ephemeral threads of plant origin and hooks made with porcupine quills (see Figure 22). The advent of nylon and metallic hooks in the middle of the twentieth century considerably increased the frequency of hook-based fisheries and boosted angling as a fully-fledged fishing activity.

\section{Fishing technique 19: Surface hook fishing}

Surface angling òlé $\mathbf{\varepsilon} \boldsymbol{\varepsilon}$ is practiced all year long. This fishing method engages people of all ages and both genders, although it is unquestionably the male youth favorite as well as a recreational activity. The basic hook line òf $\boldsymbol{\varepsilon}$ is composed of a metal hook ǹnkò nlóp tied to a nylon thread which is attached to a flexible rod mìnkpwá à nlóp made of the rachis of a Raphia palm zàm. Earthworms bə̀sáá are by far the most common baits. They are dug out from the mud of secondary riverbanks tóy (ò-/à-). The range of captured fish is very large. Hook fishing is most of the time run as a sideline of another fishing activity. It is a means to seize small fish, which in their turn serve as baits for catching larger fish via more substantial fisheries. For instance, women occasionally hook fish during the dry season as a side activity to dam fishing. 


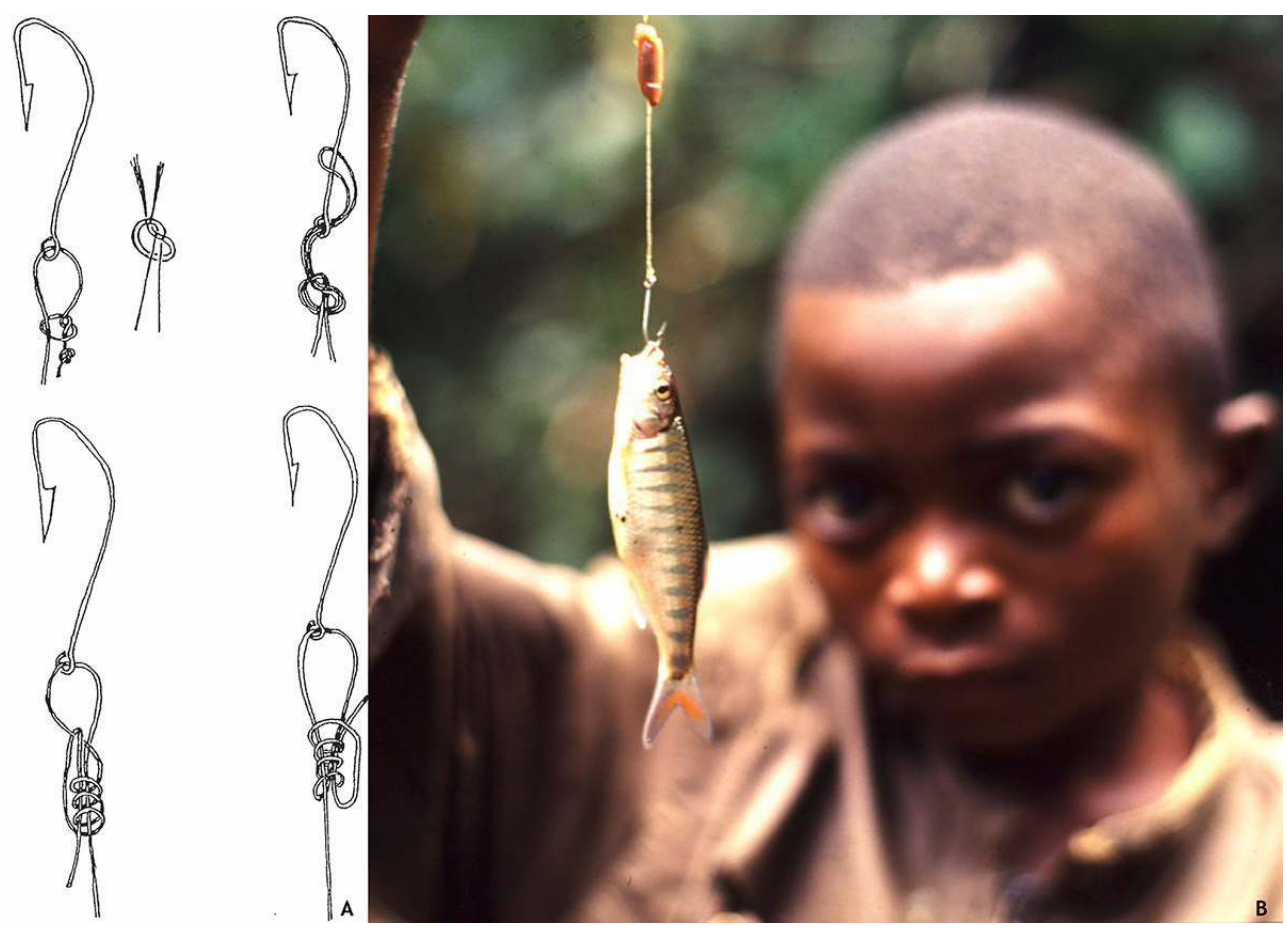

A: Various ways of tying MBÀngó a line to a hook - B: A hooked ray-finned fish Raiamas buchholzi, Cyprinidae SÀMÀ (È-/MÈ-)

(C) E. Dounias

\section{Fishing technique 20: Set of bottom hook lines in the riverbed}

Used only by the Ntumu in the Ntem loop, the bottom hook line tèlè (è-/bì-) is composed of a flexible rod made of a rachis of Raphia palm whose base has been beveled off. Depending on the depth of the watercourse, the fisherman - adult or adolescent, individually or in pairs - moves on foot or by canoe, and plants the cane directly in the bed of the watercourse. The hook is held by a short nylon wire about $15 \mathrm{~cm}$ long, which is tied about $20 \mathrm{~cm}$ above the base of the rod. Once installed, hooks and baits (earthworms) are located just above the bottom. Each fisherman possesses about thirty lines nsòm bìtélé that he installs indifferently daytime and nighttime, when the water level of category 3 streams is very low. The fishes caught are mainly species of Auchenoglanis and Clarias.

\section{Fishing technique 21: Set of surface hook lines along the riverbank}

At night and during the dry season, solitary fishermen install a series of about thirty to fifty small rattan canes nkàn (mì), ngà ( (̀̀-/bì-), lú (à-/mò-), or ngbwámán, inclined in the muddy banks of shallow and small streams. These lines are held by a forked support. The baits used are diverse: earthworms, small fry, but also Achatina snails, grashoopers, or caterpillars, which are better retained by the hook and therefore require less attention. Some fishermen also use ant larvae of Tetraponera spp., Formicidae that are harvested in the ant tree Barteria fistulosa (Passifloraceae) ìngokom. Productive mainly 
from December to May, these lines trap fish without scales kwòs bíkòp from the Bagridae family, and also electric fish, Malapteruridae.

Figure 21: Set of surface hook lines along the river bank (Mvae)

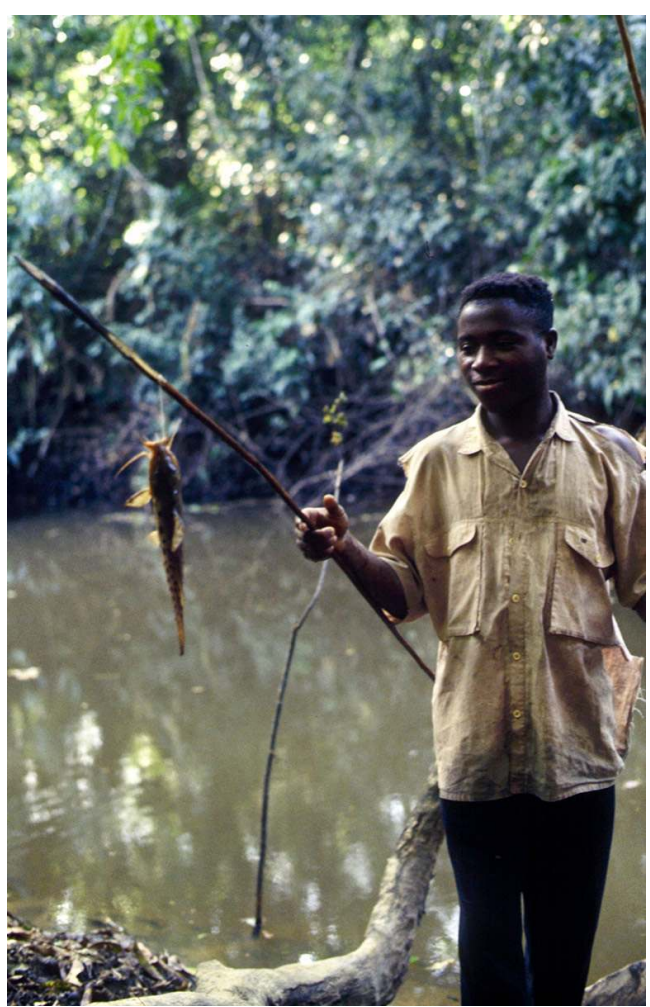

(C) E. Dounias

\section{Fishing technique 22: Longline fishing}

Whatever the season, longlines are installed in deep and calm water spots of rivers of categories 1 and 2. It is a male and solitary activity carried out by fishermen who own a canoe. A hundred of small gangions are fixed to a long lead rope that is tied to the branch of a riverbank tree hanging over the water. Pebbles serving as ballasts are tied to each gangion, and hooks are baited with the flesh of small fish or crab. Mvae and Ntumu fishermen distinguish a diurnal set-up èlobà from a nocturnal one mìsanga. During daylight, the fisherman visits his longline continuously. When he notices that a gangion has caught a fish, he ties stretches of bamboo and delays the moment to haul the fish: while desperately trying to swim away, the fish will get tired by the resistance of the floating bamboo. Barbus spp., Citharichtys stampfii and various Clariidae species are the most common diurnal catches. Nocturnal longlines are installed at sunset following the same method, but are visited only once before sunrise. Most captured fishes belong to the Bagridae, Mochokidae and Schilbeidae families.

\section{Fishing technique 23: Handline fishing with wooden float}

61 During a low-water period, in the very deep waters tól (è-/à-) of categories 1 and 2 watercourses, the fisherman lets his canoe slowly drift and throws his five-meter long 
line which is wounded around floats mbás (ì-/mì-) that are carved out of the buttress of dùm (ø/ø) Ceiba pentandra, Bombacaceae. The knot is tied to the shank of the hook in a particular manner kyغ̀n (è-/bì-) that enables to hang to 2 to 3 hooks. The coil of wire unwinds while hooks sink 1 or 2 meters below the surface. The fisherman raises the line when he sees the float fidgeting. Practiced daytime, this fishing method is preferred by teenagers and young adults.

Figure 22: Handline fishing with a wooden float (Ntumu)

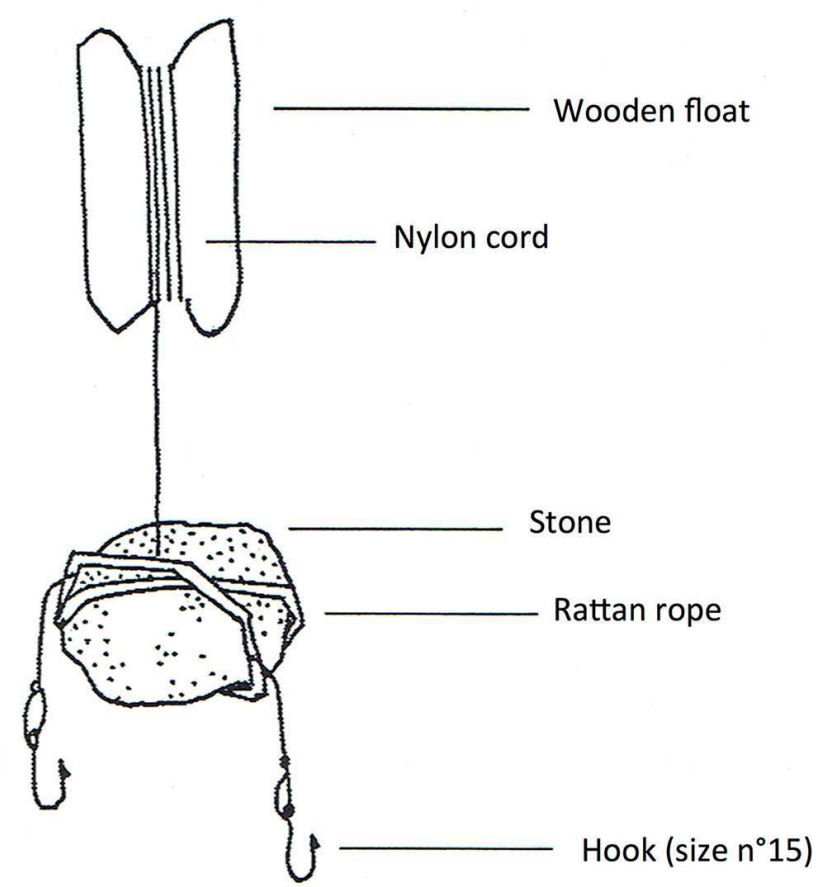

Reproduced and adapted from Cogels 2002

Fishing technique 24: Handline throwing

Handline throwing follows nearly the same procedure with the previous fishing method, with the difference that it does not target surface fish with scales but rather bottom fish without scales. No float will maintain the hooks near the surface. In the contrary, sinkers àfírá (lead generally picked out from old battery terminals) are added to drag the line down to the bottom. The line length, never less than $30 \mathrm{~m}$ long, is much longer than the one used with wooden floats. The Bagridae are the most common prey. Children, who rarely have access to canoes, sometimes throw their handlines from the riverbanks. They use long rods ngó? nkpwéć to reach the deepest water spots.

\section{Fishing technique 25: Crab catching}

63 A line is baited with a piece of steam-cooked cassava tuber and is attached to a stake that is planted in the bank of a category 3 stream. While the crab is busy eating the cassava, the fisherman dazzles it with the beam of his flashlight and carefully seizes the crab by 
hand, avoiding the claws, or knocking it beforehand with a machete. This method is essentially performed by the Ntumu and the Mvae of the Ntem loop. The coastal Mvae catch crabs in estuarine waters using the trap with non-return flap derived from that of their neighboring coastal fishermen (Yasa, Batanga) (see fishing technique 17 described above).

\section{Fishing technique 26: Catfish hook fishing using a porcupine quill}

This diurnal as well as nocturnal method of catching Clarias camerunensis ngò̀̀ and Auchenoglanis occidentalis èvos has now fallen into disuse. It is a male and individual fishing activity that is based on the use of hooks that are made with a quill of the African brush-tailed porcupine ngom Atherurus africanus, Hystricidae. The quill is bended until adopting a 10 to 20 degree angle. The bending is whipped and consolidated with a string made of fibers from Araceae plants (Rhektophyllum mirabile, Nephthytis poissonii, Cercestis sp. among others) that are generically called ndes. The quill is baited with an earthworm. The fisherman seeks catfish burrows àfùm in the shady banks right under the stilt roots mə̀sám ásì of Uapaca spp., Phyllanthaceae sàm (à-/mè-), trees whose drupes, falling directly into the water, are much appreciated by catfish. The short line is tied to a stilt root or a branch, and the angler lifts the baited quill in front of the catfish burrow and strikes up when the catfish has swallowed the hook and tries to swim backwards in its hole. If no catfish stands at the entrance, the angler introduces the baited quill into the hole, presenting it at the end of a notched pole (Figure 23) to make sure that the hook is properly oriented.

Figure 23: Catfish angling using a porcupine quill (Ntumu)

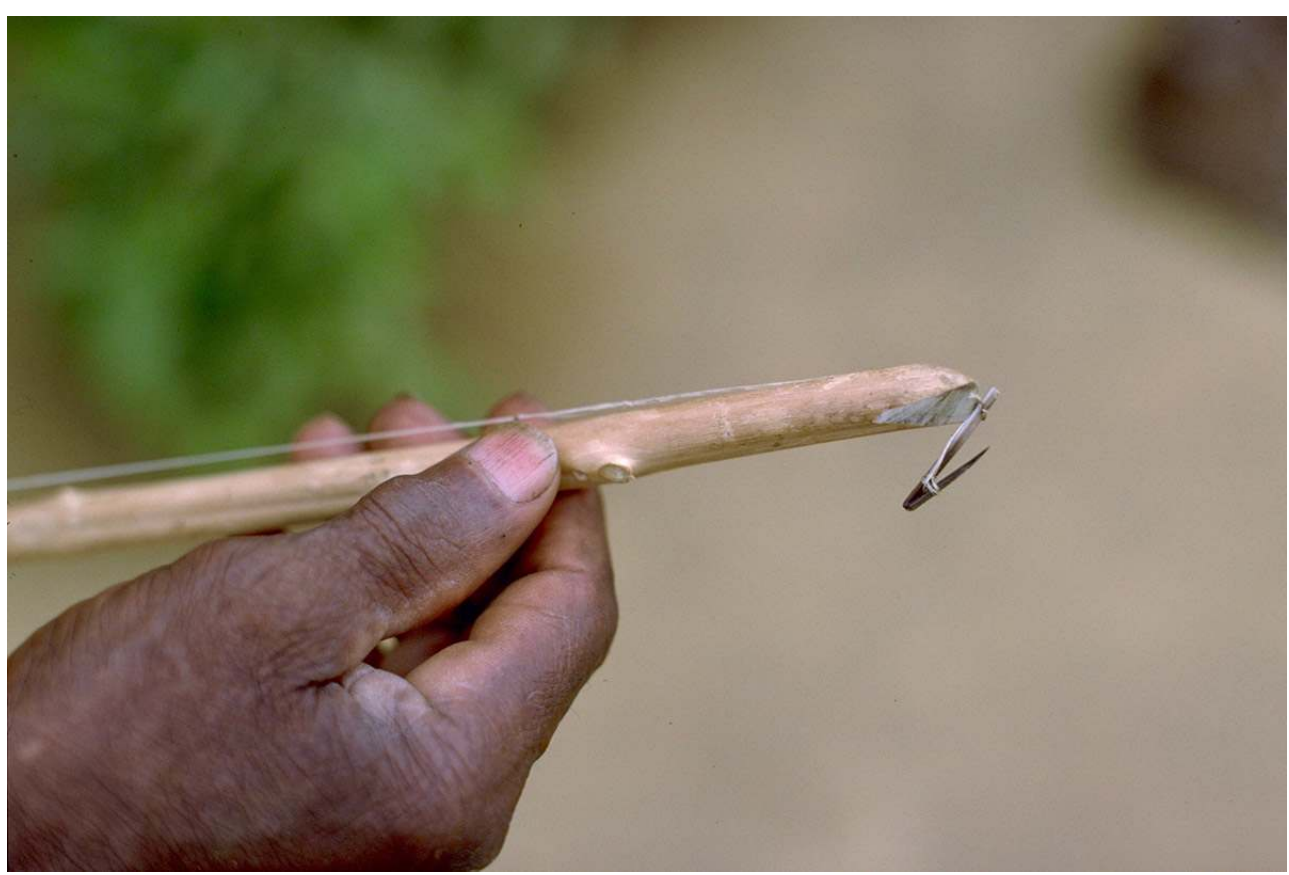

(c) E. Dounias 


\section{Other fishing techniques}

\section{Fishing technique 27: Nocturnal hand catching with flashlight and machete}

Flashlight and machete fishing is an opportunistic exploration carried out as a sideline of another activity. For instance, it is improvised by trappers during their stay in forest camps from which they visit their trap lines during the day. Success depends mainly on the dexterity of the fisherman. These nocturnal explorations are also the occasion to catch by surprise some aquatic mammals that are rarely captured otherwise, such as the giant otter shrew dzós Potamogale velox, Tenrecidae and the Cameroon clawless otter bày (à-/mè-) Aonyx capensis congicus, Mustelidae. Such explorations are much more frequent and occur at any season in the Ntem loop that is the endemic area of the coveted Goliath frog nàmwàà (ø/ø) Conraua goliath, Ranidae (Figure 24).

Figure 24: Goliath frog night catching (Ntumu)

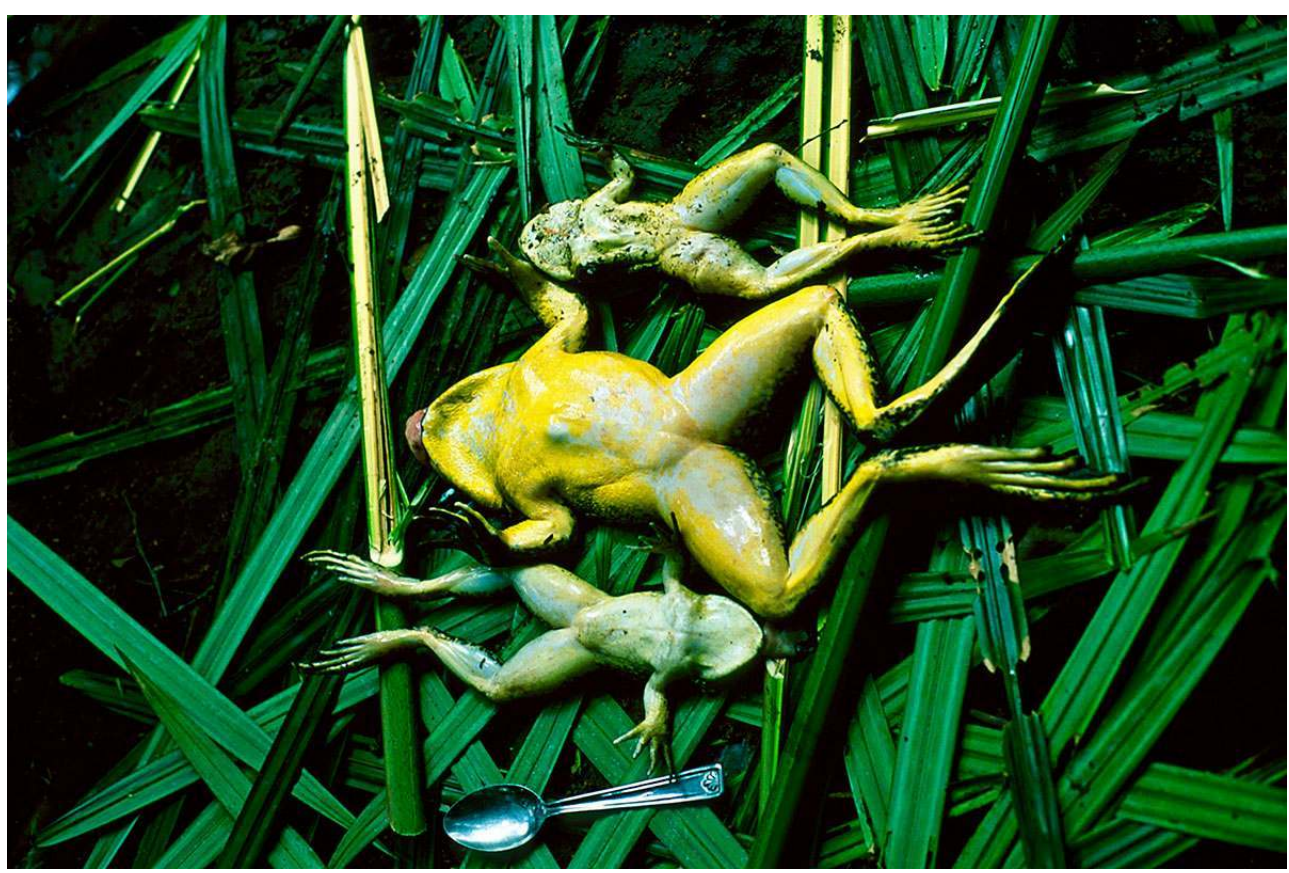

(c) S. Carrière

\section{Fishing technique 28: Poison fishing}

The capture of fish by asphyxiation is a proven practice found in all latitudes. This universality does not disprove a good knowledge of the environment, since this fishery consists in neutralizing the fish by means of narcotics, which must in return remain harmless to the consumer: the plants deemed to be ichthyotoxic are precisely selected because they do not require any detoxification of the captured fish. However, water from the poison pool should be avoided during the hours following the fishing expedition, otherwise there is a risk of gastric disorders of varying severity. In any case, the narcotic effect is temporary and does not prejudice the aquatic environment. Poison fishers 
describe fish as 'drunk' or 'breathless': the induced asphyxia forces the fish to breathe on the surface, where they are then stunned and caught by the fishers on the lookout. Other fish and mollusks are seized by passivity and are then easily caught in the water holes along the banks. A poison fishing expedition is always prepared collectively and it involves all the members of the village and surroundings. It takes place in the category 2 watercourses, preferably during the dry season.

As shown in Figure 25, plants known by the Mvae and the Ntumu for their ichthyotoxic properties belong to all biological types, and cover the whole spectrum of domestication. Some are pseudo-domesticate aquatic herbaceous plants or bushy shrubs - such as Justicia extensa, Acanthaceae and Bertiera elabensis, Rubiaceae - whose thickets growing on the riverbanks are maintained in purpose. Other are light undergrowth trees like Albizia coriaria, Mimosaceae that farmers maintain in their coffee or cocoa plantations. Many are woody lianas such as Strychnos spp., Loganiaceae and Strophantus gratus, Apocynaceae respectively sources of strychnine alkaloid and strophantine glycoside, secondary compounds that have for long been valorized as cardiac stimulants by the pharmaceutical industry - or more slender creepers such as Adenia gracilis, Passifloraceae and Nephthytis poisonii, Araceae. Some of the plants used for poison fishing are also spices: they contain antimicrobial compounds that are accordingly consumed sparingly: Scorodophloeus zenkeri, Mimosaceae (garlic-like scent and taste), Tetrapleura tetraptera, Mimosaceae (African spicy black stew), Zanthoxylum spp., Rutaceae (a common condiment in Cameroonian gastronomy), and Piper guineense, Piperaceae (wild pepper). Some ichthyotoxic plants are grown exclusively for this purpose: Tephrosia vogelii, Caesalpiniaceae, is an emblematic poison fishing shrub that is planted in homegardens. Aralioides cissus, Vitaceae, Datura spp., Solanaceae, and Dieffenbackia picta, Araceae, are also planted in the homestead as ornamental plants. Like many ornamental plants, these evergreen plants secrete toxic or hallucinogenic secondary compounds. In the case of Dieffenbackia picta that is more frequently used by the Ntumu than by the Mvae, it is recommended to remove the gills of the captured fish before cooking them. The common presence of the shrub Oubanguia alata, Lecythidaceae, in the homegardens is primarily due to its alexiteric (anti-venom) properties. Some plant parts intervene only as adjuvants in the poison preparation, like the bark of the woody liana Tetracera alnifolia, Dilleniaceae.

Figure 25: Ichthyotoxic plants used by the Mvae and the Ntumu for poison fishing

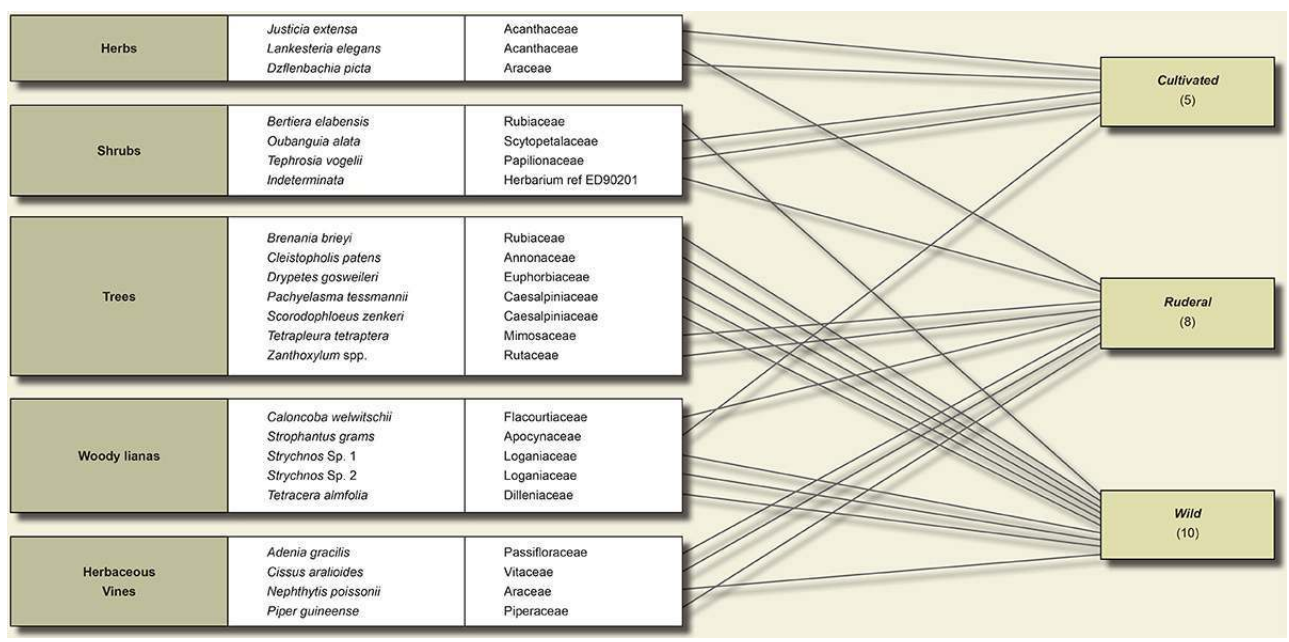



This collective fishery is a major occasion for rallying several adjoining villages. The decision to organize the fishery must be taken jointly so that everyone is informed of the temporary pollution of the river. Anyone who is getting caught violating this principle and pouring poison fishing plants on the quiet, will endure heavy penalties that can go as far as banishment. These socio-political safeguards are also attempts to discourage the adoption of plants substitutes that are now increasingly used by unscrupulous fishers in search for easy money: synthetic chemical pesticides (anticapsid and antifungal treatments) are diverted from their initial use in cocoa plantations. They lastingly pollute the watercourses, destroy aquatic fauna and flora, and expose fish consumers to severe food poisoning. The use of ichthyotoxic plants is accompanied by special socio-symbolic proscriptions like sexual abstinence, which preludes to most large-scale undertakings. Among the Mvae, no food should be left near poison fishing plants, otherwise the food will be polluted and the plant will loose its narcotic potency. Pregnant women must also avoid any contact with these plants and are not allowed to touch waters in which the narcotics have been poured. The risk involved is a double abortion: of the fishing expedition and of the future mother. practice for years by the Mvae, and its performance has become very anecdotal among the Ntumu. In the Ntem loop, it is mainly conducted during the shallow waterflow season of July-August, which corresponds to the long school holidays thus to a massive participation of children.

Figure 26: Some of the most commonly used poison-fishing plants (Mvae and Ntumu)

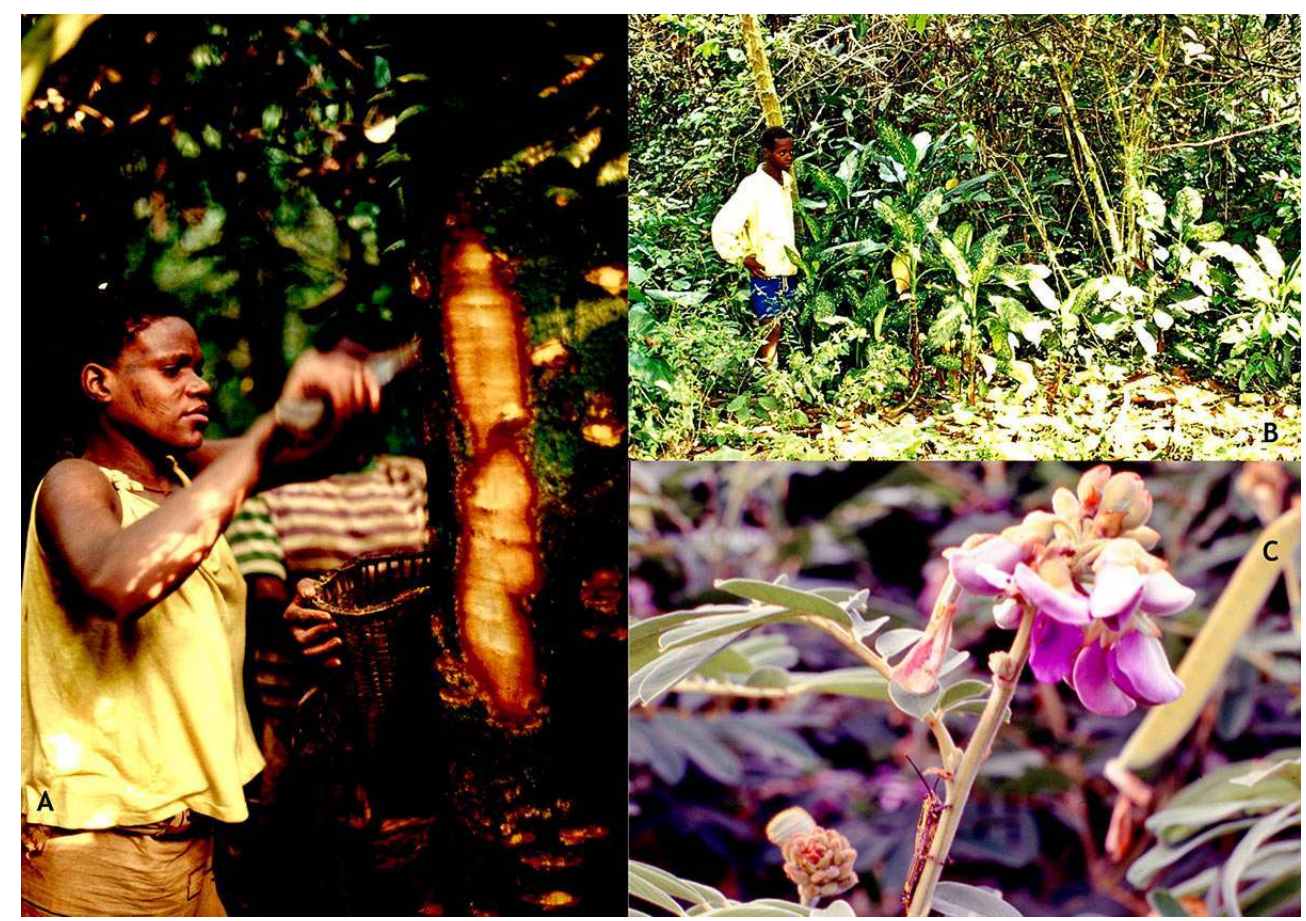

A: Bark of Zanthoxylum sp., Rutaceae - B: Leaves of Diffenbachia picta, Araceae - c: Leaves of Tephrosia vogelii, Papilionaceae

(c) E. Dounias 


\section{Fishing technique 29: Pond}

70 It is during the month of March, when the water begins to recede from the small flooded arms ǹndwundwa of category 4 wetlands, that the signal is given for this male fishery, practiced alone or in pairs and reserved for confirmed fishermen. The chosen stream is carefully cleaned up (elimination of plant debris) 'so that the fish sees the food well'. The fisherman erects a barrier ǹndzib étò? formed of jointed wooden stakes or panels of unrolled bark of Annonaceae trees. An entrance is topped by a scaffolding, from which the fisherman can block the entrance or leave it open at his discretion, by sliding up and down a panel of bark mbé éto?. Each day, the fisherman will feed the pond with crushed blocks of anthill dùma. Preferred ant species are sòn (è-/bì-) Crematogaster spp., Formicidae, ǹndza (indeterminata), and ngurú (indeterminata). The fish are attracted by the floating larvae tùm (è-/bì-) and formic acid exhaled from these pieces. During the day, they enter the pond, which will be closed at nightfall. Day after day, the fisherman renews the food and reopens the gate, to attract more fish and to let the visiting fish coming in and out freely. The operation can last several weeks until the water level shows signs of receding. The fisherman then definitely locks the entrance early before dawn, and bails the water out of the pond. The catches are abundant and reward the patience of the fisherman. This demanding technique can be assimilated to a pseudo-domestication practice, and it is reserved to elderly fishermen who are too old to engage in more physical fishing activities and who can dedicate time to imposed frequent visits of the pond for feeding the fish. Clarias and Marcusenius catches are top ranked before other catches like Xenocharax spirulus, Brycinus tessmannii, Brycinus macrolepidotus, Micralestes spp., Citharichtys stampflii, Hepsetus odoë, and Hemichromis fasciatus.

Figure 27: Pond building in a flooded lowland forest (Ntumu)

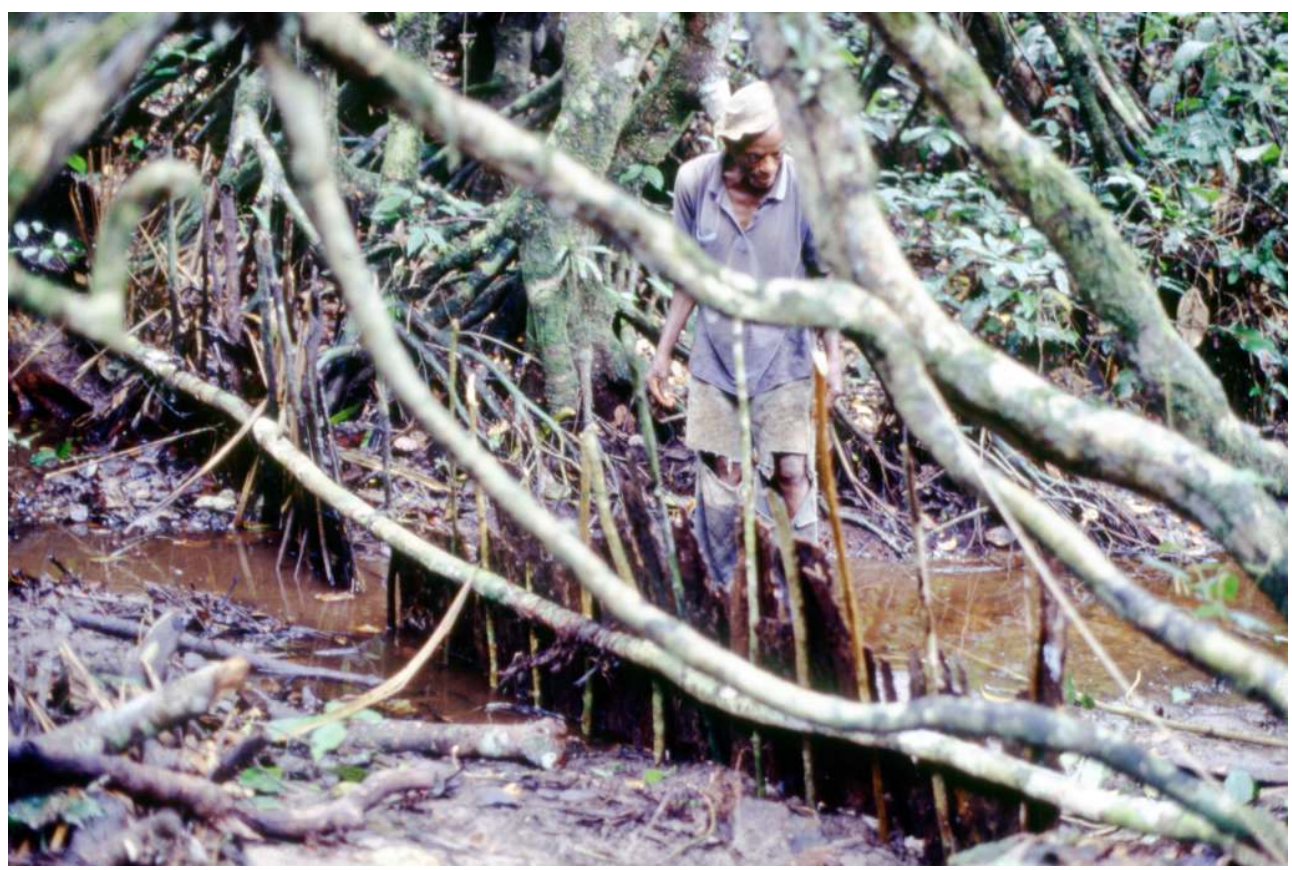

(c) E. Dounias 


\section{Fishing technique 30: Catfish pit}

71 During the rainy season, a pit is excavated perpendicularly to the bed of the streambed on one of the shores of a category 3 stream. This pit is two meters wide and deep and enters the shore for about four meters. A scaffolding allows the fisher to stand upright the entrance that can be quickly obstructed vertically by sliding bark panels. In the opposite side of the entrance, the fisherman deposits blocks of anthills and termite mounds, full of larvae and impregnated with formic acid. Early before dawn, the fisherman discreetly goes to the pit and locks the entrance. Unlike the pond described above (see fishing technique $n^{\circ} 29$ ), which is a form of pseudo-domestication by continued feeding and gradual habituation of the fish, pit closing and catching of the trapped fish are repeated on a daily basis. Clarias catfishes and, in a lesser proportion, Marcusenius elephant fishes are by far the dominant catches of this pit.

\section{Seasonality and complementary of fishing methods}

\section{Seasonality}

72 As already pointed out in the description of the Mvae and Ntumu typology of watercourses, water level is the most salient and dynamic process influencing the local perception of water dynamics by the fishers. This water-level driven typology induces wild fisheries that generally concentrate in waters of categories 3 and 4 during the rainy season. By contrast, dry season wild fisheries preferably occur in waters of categories 1 and 2. Some activities can be conducted all year long when their practice can be shifted from one watercourse category to another (Figure 28). Most importantly, the diversity of fishing methods and sociocultural rules for their practice (Figure 29) supports the ability to capture fish and shellfish all over the year.

Quantitative food surveys carried out among the western Mvae of the Ntem river estuary (Koppert et al. 1993) pointed out seasonal fluctuations in fish consumption: $18 \mathrm{~g} / \mathrm{capita} /$ day on average during the small dry season (July); $64 \mathrm{~g} / \mathrm{capita} /$ day during the long dry season (December); $42 \mathrm{~g} /$ capita/day during the short rainy season (April). Even if the consumption of bushmeat largely exceeds that of fish $(216 \mathrm{~g} / \mathrm{per}$ capita/day on average all over the year), the higher consumption of fish during the long dry season strongly coincides with a drop in bushmeat consumption (Dounias 1993, Pagezy 1988). Driest seasons are known to be less favorable for mammal hunting (Yasuoka et al. 2015) and protein-rich fish nicely compensate the shortage in bushmeat availability. 
Figure 28: Capture of a dwarf crocodile (Osteolaemus tretapis, Crocodilidae) using specific traps that are installed in the riverbanks (Mvae)

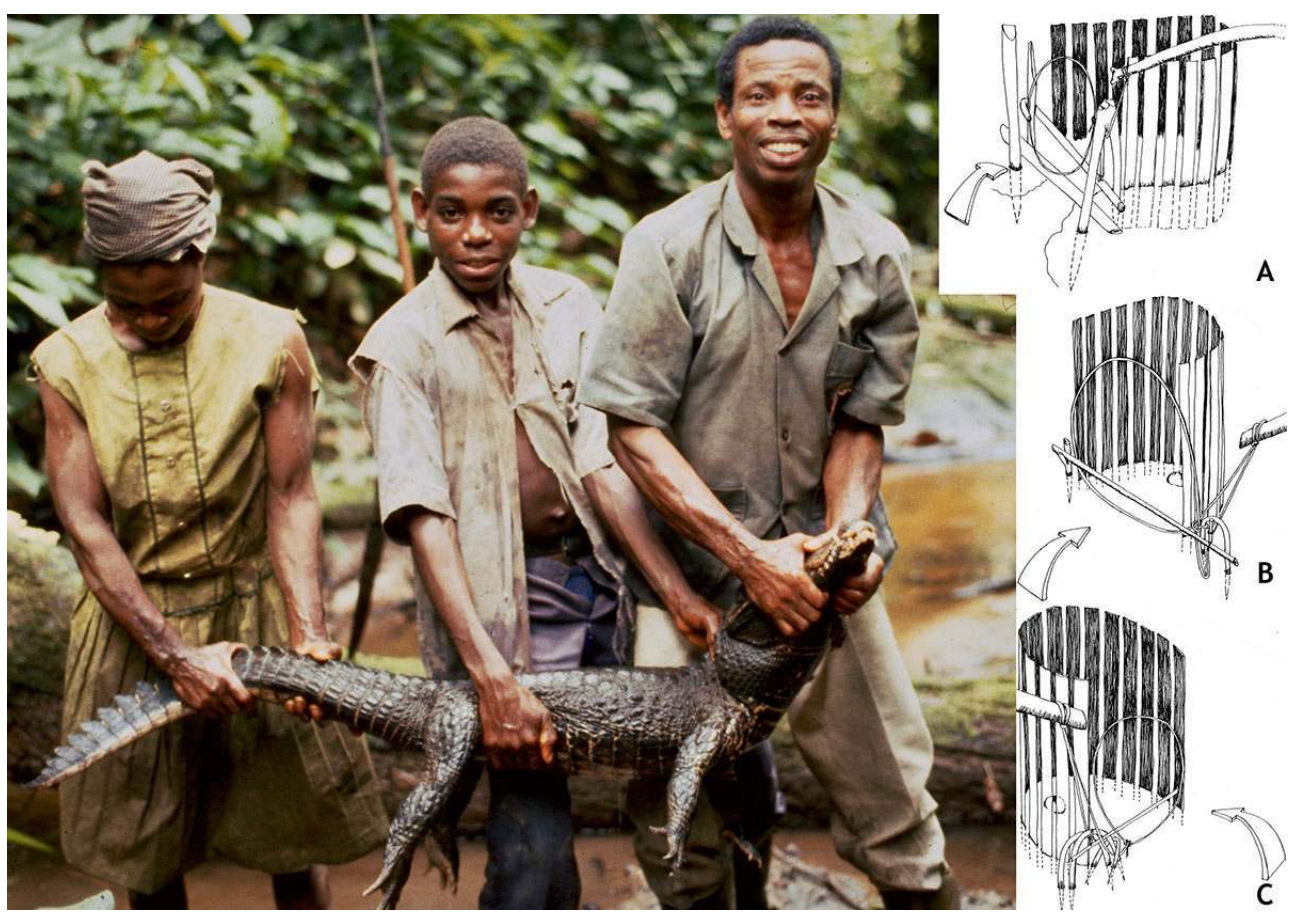

A: JúN - B: ÀFòKó - C: òLÀmà DZə́s, also used to catch the giant otter shrew Potamogale velox, Tenrecidae

Figure 29: Socio-ecological features of Mvae and Ntumu fishing methods

\begin{tabular}{|c|c|c|c|c|c|c|}
\hline & Code & Fishing techniques & $\begin{array}{l}\text { Male adutt (M) } \\
\text { Female adut (F) } \\
\text { Child (C) }\end{array}$ & $\begin{array}{l}\text { Individual (I) } \\
\text { Pair working (P) } \\
\text { Collective (C)) }\end{array}$ & $\begin{array}{l}\text { Inland water } \\
\text { category }\end{array}$ & $\begin{array}{c}\text { Diume (D) } \\
\text { Nocturnal (N) }\end{array}$ \\
\hline \multirow{6}{*}{ Nets } & 1 & Gillnetting & M & 1 & 1 & $\mathrm{~N}$ \\
\hline & 2 & Gillnetting with beaters & $M, F, C$ & c & 2 & D \\
\hline & 3 & Lift net & M & I, P (Mvae), C (Ntumu) & 3 & $\mathrm{D}, \mathrm{N}$ \\
\hline & 4 & Large cast net & M & 1 & 2 & D.N \\
\hline & 5 & Large cast net combined with gillnetting & M & c & 3 & $\mathrm{~N}$ \\
\hline & 6 & Small cast nest with bait & M, C & 1 & 3.4 & D \\
\hline \multirow{4}{*}{ Dams } & 7 & Dam fishing & $\mathrm{F}$ & c & 2 & D \\
\hline & 8 & Heap of wood shelter & F.C & I,P & 3 & D \\
\hline & 9 & Baling with a scoop net & F.C & c & 2,3 & D \\
\hline & 10 & Platiom & M & c & 2 & D. N \\
\hline \multirow{8}{*}{$\begin{array}{l}\text { Woven basket } \\
\text { traps }\end{array}$} & 11 & Fence including single chamber basket traps & $\mathrm{F}$ & I,P & 2,3 & $\mathrm{~N}$ \\
\hline & 12 & Immersed rattan basket with plant bait & A.C & c & 2 & $\mathrm{~N}$ \\
\hline & 13 & Open woven basket trap & M & $\mathrm{P}$ & 23 & D \\
\hline & 14 & Shrimp basket trap with bait & F (Mvae), M (Numu) & I,P & 3 & D \\
\hline & 15 & Catish basket trap with bait & M & I,P & 3,4 & D \\
\hline & 16 & Hood for cattish & M & c & 2.3 & D \\
\hline & 17 & Woven basket trap with non-retum flap & $M, C$ & $1, P$ & 2,3 & $\mathrm{~N}$ \\
\hline & 18 & Bottom double-chamber basket trap with bait & M & 1 & 1.2 & D \\
\hline \multirow{8}{*}{ Hooks } & 19 & Surface hook fishing & $M, F, C$ & 1 & $1,2,3,4$ & $\mathrm{D}, \mathrm{N}$ \\
\hline & 20 & Set of bottom hook lines in river bed & M, C & $1, P$ & 3 & D.N \\
\hline & 21 & Set of surface hook lines along the river bank & M & $1, P$ & 3,4 & $\mathrm{~N}$ \\
\hline & 22 & Longline fishing & M & 1 & 1,2 & N.D \\
\hline & 23 & Handine fishing with wooden float & M & 1 & 1,2 & D \\
\hline & 24 & Handline throwing & M & 1 & 1,2 & D \\
\hline & 25 & Crab catching & M & P,C & 3 & $\mathrm{~N}$ \\
\hline & 26 & Cattish hook fishing using porcupine quill & M & 1 & 3 & $\mathrm{~N}$ \\
\hline \multirow{4}{*}{ others } & 27 & Nocturnal hand catching with flashight and machete & M & $P, C$ & $2,3,4$ & $\mathrm{~N}$ \\
\hline & 28 & Poison fishing & M,F,C & c & 2,3 & D \\
\hline & 29 & Pond & M & I,P & 3 & $\mathrm{~N}$ \\
\hline & 30 & Cattish pit & M & 1,P & 4 & $\mathrm{~N}$ \\
\hline
\end{tabular}

See Figure 4 for corresponding inland watercourse categories 


\section{Complementarity}

74 The inventory of the various fishing methods reveals how jointly some of these methods are frequently carried out. Many fishing activities proceeds along the same principle that characterizes trapping (Dounias 2000): fish are captured by a device or a structure that anticipates their behavior and that generally operates in the absence of the fisher. When the installation is ready, the fishers have time to kill and they can devote this time to other fishing activities. Some fishing activities supplement one another or may be carried out one after another. Daytime angling is typically a form of fishery that occupies the adult fishers (men and women) during 'time-out' moments occurring during another fishing activity. Angling also precedes other fishing techniques that require the use of small fish as baits. The visit of shelters of pill-up sticks frequently coincides with dam fishing when the watercourse chosen for a dam fishing expedition contains pre-installed shelters. Women regularly perform nocturnal scoop net fishing in parallel to 'couvre feu', a male wild fishery that is based on a combination of cast net throwing and gillnetting. Scoop nets allow the catching of the fish that escaped the 'couvre-feu' by finding refuge in the bank anfractuosities. Tessmann reports that small single-chamber basket traps yá (à-/mè-) (see fishing technique $\mathrm{n}^{\circ} 14$ ) were systematically associated with doublechamber basket traps nkóy (see fishing technique $n^{\circ} 18$ ), although they tend to be performed separately today. Fences ndzíp (see fishing technique $n^{\circ} 11$ ) regularly host basket traps of different shapes: nsoy (see fishing technique $\left.n^{\circ} 13\right)$, yá (à-/mè-) (see fishing technique ${ }^{\circ} 14$ ), nkwéy (see fishing technique $n^{\circ} 15$ )... The inlets of these traps are oriented distinctively (upstream versus downstream), some include baits, others do not, and the synergy of their associations broadens the diversity of catches.

These few examples show that the impressive diversity of fishing techniques conceived by these non-fulltime fisherfolks is amplified by a multitude of possible combinations that are aimed to adjust the fishing activity to the specificities of each warecourse microhabitat. The flexibility provided by a vast range of techniques conciliates with farsightedness and a good sense of opportunity to forge an incredible range of fishing possibilities.

\section{When fishing meets with hunting}

Similarly, many fishing expeditions are side activities to agricultural, gathering, trapping, and hunting activities. Again, sense of opportunity and flexibility are determining factors of multi-active subsistence strategies that enable forest dwellers to easily shift from one activity to another.

The distinction between fishing and hunting is blurred by the fact that many mammals and reptiles are killed during wild fisheries using dams. Oishi (this issue) similarly notices that the Bakwele of southeastern Cameroon make no clearcut distinction distinction between fishing and hunting, and perceive the hydrographic network and terra firma as non distinctive components of a unique ecotone. A particular form of activity that lies at the frontier between fishing and trapping is the dwarf crocodile trapping. The Mvae and the Ntumu have elaborated specific traps (Figure 30) that are set up in the banks of categories 3 and 4 watercourses and that are implemented only during fishing expeditions. In their classification of activities, the Mvae and the Ntumu categorize dwarf 
crocodile catching as a fishing activity, not as a hunting-trapping one. These traps installed by solitary adult fishermen are baited with snails, crabs, frogs or fish. Traps are set up at night, because the dwarf crocodile is mainly a nocturnal predator, spending most daylight hours hidden in small pools or in deep burrows. The dwarf crocodile excavates burrows extending under the banks and it uses these burrows as refuges during the dry season (Eaton 2010). For this reason, dwarf crocodile catching can occur anytime during the year, with a peak during early rainy seasons, when the crocodiles build their mounds against the base of a tree for nesting (Eaton 2004). Because of its high market value, the dwarf crocodile is the only non-fish inland water vertebrate that is targeted by a specific catching method. It is of particular importance in the commercialization of African wildlife. For that reason, catching methods are purposely conceived to capture the dwarf crocodile alive: crocodiles are among the few species capable of being transported live over long distances without the need for refrigeration (Thorbjarnarson \& Eaton 2004). To a lesser extent they are also sold as bushmeat and for their skin that is tanned for the local production of leather goods.

Figure 30: Seasonal occurrence of fishing methods

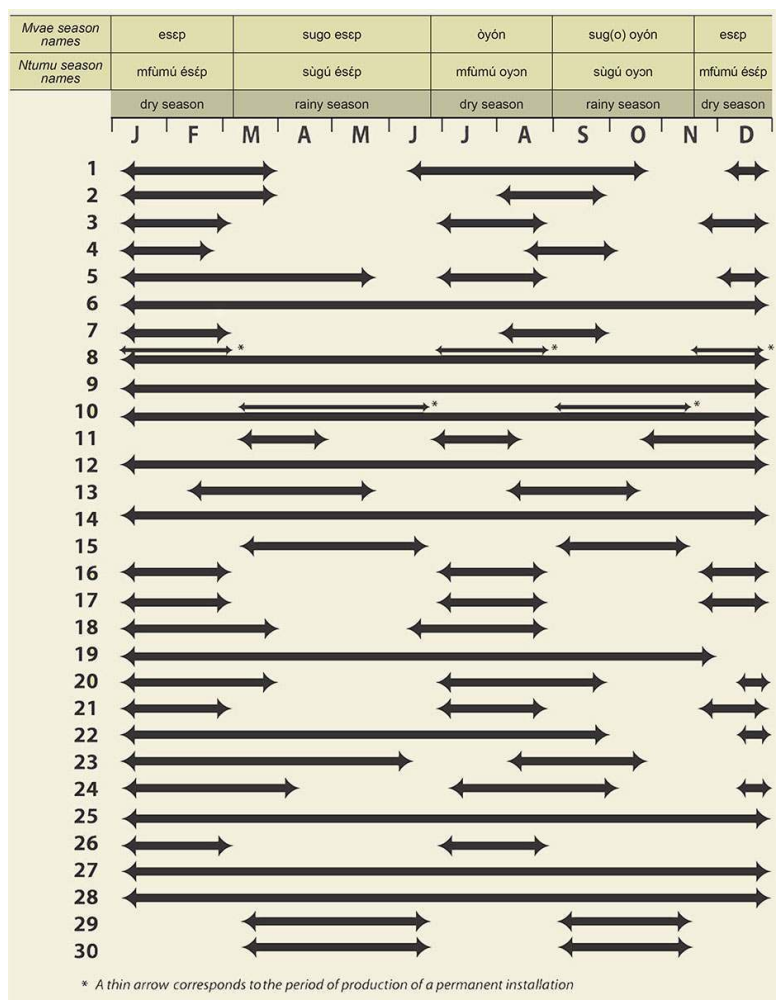

See Figures 5 and 29 for corresponding codes

\section{Conclusion}

In remote rural areas like the Ntem river watershed, small-scale wild fisheries play a fundamental role in local economies. They strengthen the local livelihoods primarily through their role in food security and, to a lesser extent, as a valuable source of cashincome (Béné et al. 2009). The paper has tried to stress the essential yet underestimated role of wild fisheries in the livelihoods of non-professional fishers in the Congo Basin. 
Inland wild fisheries are rooted in socially and culturally complex societies whose livelihoods depend on multi-faceted land use systems. The motivation behind such systems is first and foremost to satisfy food self-sufficiency. The deliberate intention of these forest dwellers is to optimize the overall system of production, not to maximize the production of a given resource. Non-professional fisherfolks rely on vast corpuses of fishing methods that take advantage of diversified aquatic environments. In essence, wild fisheries are seldom prone to modernization through mechanization and industrialization. They are fundamentally driven by individual human effort and this effort is not in the hands of a narrow circle of experts, but on the contrary distributed over all the social categories of the society - men and women, adults and children, individuals and groups of various sizes. Even if sales of fish may occur occasionally in local markets, the prominent function of this fish production is neither aimed to target market economy nor to create wealth and income, but to secure local food dietary regimes by supplying protein-rich and tasty wild food. Within a changing world where development agencies tend focus on income generating solutions for poverty alleviation, too little attention is given to the role of wild fisheries, with regard to food security and the maintenance of ecosystem services (De Graaf et al. 2015).

Despite of the dramatic lack of empirical data, the few studies dedicated to wild fisheries in the Congo Basin converge to show that the richness of inland aquatic fauna is totally underestimated. The small-scale wild fisheries of the Mvae and the Ntumu - but also of many other forest-dwellers like the Badjoue (Abe'ele Mbandzo'o 2001), the Nunu (Harms 1989), the Bakwele (Oishi 2014, this issue) and the Baka (Gallois \& Duda this issue) - act as a safety net. For most Congo Basin small-scale farmers, the domestic consumption of inland aquatic fauna forms a key side of smallholder coping strategies as it secures dietary regimes between harvests, or in times of drought, flooding, crop failure and other types of emergency. Although contested by the defenders of the economic approach of sustainability (Wunder et al. 2014), the safety-net function of biodiversity and wild foods is widely acknowledged (McSweeney 2003, Arnold et al. 2011), particularly during times of low agricultural production (Angelson \& Wunder 2003), during seasonal or cyclical food gaps (Vinceti et al. 2008), or during periods of climate induced vulnerability (Cotter \& Tirado 2008). But the safety net role of wild fisheries deserves utmost attention. It should encourage development agencies to conceptualize their interventions in terms of theirs effects on livelihood systems, rather than assessing specific income-generating activities in isolation from or, worse, in opposition to other activities within these multi-faceted land-use strategies. This paper is thus also an attempt to contradict the conventional discourse that small-scale fisheries and rural poverty are intimately correlated (Béné 2003). This discourse, which is conveyed by a sweeping rhetoric - "fishermen are the poorest of the poor" or "fishing is the activity of last resort" (Béné et al. 2008) - has facilitated a consensual adhesion around the idea that fishing communities are structurally and chronically poor.

One last lesson to retain from the study of the Mvae and the Ntumu fishery complex is the astounding capacity of the fishers to plan their fishing activities throughout the year and to modulate or combine their various fishing methods in accordance with the seasonal fluctuations of water level and their incidence on watercourse microhabitats. As stressed a while ago by Colfer et al. (1999), increased effort should be made to analyze the indigenous ways of perceiving time and scheduling their activities accordingly. 


\section{BIBLIOGRAPHY}

Abe'ele Mbanzo'o P. 2001 - La pêche traditionnelle badjoué : appropriation d'une ressource mobile. In Delvingt W. (Ed.), La forêt des hommes : terroirs villageois en forêt tropicale africaine. Gembloux, Les Presses Agronomiques de Gembloux : 43-64.

Alexandre P. 1965 - Protohistoire du groupe beti-bulu-fang: essai de synthèse provisoire. Cahier d'Études Africaines 5 (20) : 503-560.

Allison E.H. \& Ellis F. 2001 - The livelihoods approach and management of small-scale fisheries. Marine Policy 25 : 377-438.

Angelson A. \& Wunder S. 2003 - Exploring the forest-poverty link: key concepts, issues and research implications. Bogor, Centre for International Forestry Research, CIFOR Occasional Paper 40, 58 p.

Arnold M., Powell B., Shanley P., \& Sunderland T. 2011 - Editorial: Forests, biodiversity and food security. International Forestry Review 13 (3) : 259-264.

Bahuchet S. 1992 - Esquisse de l'ethno-ichtyologie des Yasa du Cameroun. Anthropos 87 : 511-520.

Béné C. 2003 - When Fishery Rhymes with Poverty: A First Step Beyond the Old Paradigm on Poverty in Small-Scale Fisheries. World Development 31 (6) : 949-975.

Béné C., Steel E., Luadia B.K. \& Gordon A. 2009 - Fish as the "bank in the water" - Evidence from chronic-poor communities in Congo. Food Policy 34 : 108-118.

Bostoen K., Clist B., Doumenge C., Grollemund R., Hombert J.-M., Muluwa J.K. \& Maley J. 2015 - Middle to late Holocen paleoclimatic change and the early Bantu expansion in the rain forests of western Central Africa. Current Anthropology 56 (3) : 354-384.

Carrière S.M. 1999 - Les orphelins de la forêt : influence de l'agriculture sur brûlis des Ntumu et des pratiques agricoles associées sur la dynamique forestière du sud-Cameroun. Doctoral thesis, Université Montpellier II, Sciences et Techniques du Languedoc, $448 \mathrm{p}$.

Carrière S.M. 2003 - Les orphelins de la forêt. Pratiques paysannes et écologie forestière (Les Ntumu du Sud-Cameroun). Paris, IRD Éditions, 374 p. (À travers champs).

Carrière S.M., André M., Letourmy P., Olivier O. \& McKey D.B. 2002a - Seedrain beneath remnant trees in a slash-and-burn agricultural system in southern Cameroon. Journal of Tropical Ecology 18 : 353-374.

Carrière S. \& Castro Carreno M. 2003 - Quand les Ntumu lèvent les yeux vers le ciel, des perceptions de la forêt aux utilisations agricoles au Sud-Cameroun. Journal des Africanistes 73 (1) : 95-110.

Carrière S.M., Letourmy P. \& McKey D.B. 2002b - Effects of remnant trees in fallows on diversity and structure of forest regrowth in a slash-and-burn agricultural system in southern Cameroon. Journal of Tropical Ecology (2002) 18 : 375-396. DOI:10.1017/S0266467402002262

Chapman L.J. 2001 - Fishes of African rain forests. In Weber W., White L.J.T., Vedder A. \& Naughton-Treves L. (Ed.), African rain forest ecology and conservation: An interdisciplinary perspective. New Haven, Yale University Press : 263-290. 
Chauveau J.-P., Jul-Larsen E. \& Chaboud C. 2000 - Les pêches piroguières en Afrique de l'Ouest; pouvoirs, mobilités, marchés. Paris, Editions Karthala, IRD, CMI, 385 p.

Cogels S. 2002 - Les Ntumu du Sud-Cameroun forestier: une société de non-spécialistes. Stratégies d'usage des ressources et enjeux du changement. Doctoral Thesis, Bruxelles, Faculté des Sciences sociales, politiques et économiques.

Colfer C.J.P., Wadley R.L. \& Venkateswarlu P.1999 - Understanding local people's use of time: a pre-condition for good co-management. Environmental Conservation 26 (1) : 41-52.

Comptour M., Caillon S. \& McKey D. 2016 - Pond fishing in the Congolese cuvette: a story of fishermen, animals, and water spirits. Revue d'ethnoécologie 10.

Cotter J. \& Tirado R. 2008 - Food security and climate change: the answer is biodiversity. A review of scientific publications on climate change adaptation in agriculture. Amsterdam, Greenpeace, 8 p.

Crean K., Symes D. (Ed.) 1996 - Fisheries management in crisis. Oxford, Fishing News Books, Blackwell Science.

De Graaf G., Bartley D., Jorgensen J. \& Marmulla G. 2015 - The scale of inland fisheries, can we do better? Alternative approaches for assessment. Fisheries Management and Ecology 22 : 64-70.

Delvingt W. (Ed.) 2001 - La forêt des hommes. Terroirs villageois en forêt tropicale africaine. Gembloux, les Presses Agronomiques de Gembloux, 288 p.

Dounias E. 1993 - Dynamique et gestion différentielles du système de production des Mvae du SudCameroun forestier. Montpellier, thèse, université des Sciences et Techniques du Languedoc, $644 \mathrm{p}$. Dounias E. 1995 - Compte-rendu de mission en pays ntumu dans la boucle du Ntem, 10-20 décembre 1994. Yaoundé, Programme APFT DG VIII de l'UE, 17 p.

Dounias E. 1996a - Agriculture des Mvae du sud Cameroun littoral forestier : étude dynamique des composantes de l'agroécosystème et des plantes cultivées alimentaires. In Froment A., Garine I. de \& Binam Bikoï C. (Ed.), Anthropologie alimentaire et développement en Afrique intertropicale : du biologique au social. Paris, ORSTOM-L'Harmattan : 155-172.

Dounias E. 1996b - Recrûs forestiers post-agricoles : perceptions et usages chez les Mvae du sud Cameroun forestier. Journal d'Agriculture Traditionnelle et de Botanique Appliquée 38 (1) : 153-178.

Dounias E. 2000 - Le câble pris au piège du conservateur, technologie du piégeage et production cynégétique chez les Mvae du sud Cameroun forestier. In Bahuchet S., Bley D., Pagezy H. \& Vernazza-Licht N. (Ed.), L'Homme et la forêt tropicale. Châteauneuf de Grasse, Editions de Bergier : 281-300.

Dounias E. 2011 - La pêche chez les peuples forestiers d'Afrique centrale. In Paugy D., Lévêque C. \& Mouas I. (Ed.), Poissons d'Afrique et peuples de l'eau. Marseille, IRD Éditions : 209-231.

Dounias E. 2016 - From subsistence to commercial hunting : Technical shift in cynegetic practices among southern Cameroon forest dwellers during the 20th. Ecology and Society 21 (1) : 23. DOI: 10.5751/ES-07946-210123

Dounias E. \& Bahuchet S. 2000 - Habitat semi-permanent en forêt d'Afrique centrale. In Brun B., Dufour A.-H., Picon B. \& Ribéreau-Gayon M.-D. (Ed.), Cabanes, cabanons et campements. Formes sociales et rapports à la nature en habitat temporaire. Châteauneuf-de-Grasse, Éditions de Bergier : 161-181.

Dounias E. \& Hladik C.-M. 1996 - Agroforêts mvae et yasa du Cameroun littoral : fonctions et structures. In Hladik C.-M., Hladik A., Pagezy H., Linares O.F., Koppert G.J.A. \& Froment A. (Ed.), 
L'alimentation en forêt tropicale : interactions bioculturelles et applications au développement. Paris, Unesco-Parthenon : 1103-1126.

Eaton M.J. 2004 - 2nd Annual Report on the WCS Central African Crocodile Research Program: Congo and Gabon. Global Crocodile Conservation Program. New-York, Wildlife Conservation Society.

Eaton M.J. 2010 - Dwarf Crocodile Osteolaemus tetraspis. In Manolis S.C. \& Stevenson C. (Ed.), Crocodiles. Status Survey and Conservation Action Plan. Third Edition. Darwin, Crocodile Specialist Group : 127-132.

Gabriel O., Lange K., Dahm E. \& Wendt T. (Ed.) 2008 - Fish catching methods of the world 4th edition. Oxford, Blackwell Publishing Ltd, $536 \mathrm{p}$.

Gallois S. \& Duda R. 2016 - Beyond productivity: The socio-cultural role of fishing among the Baka of southeastern Cameroon. Revue d'ethnoécologie 10.

Gartlan S.J. 1989 - La conservation des écosystèmes forestiers du Cameroun. Gland, UICN, 186 p.

Guthrie M. 1967-70 - Comparative bantu: an introduction to the comparative linguistics and prehistory of the Bantu languages. London, Gregg Press Ltd.

Harms R. 1989 - Fishing and systems of production: The precolonial Nunu of the middle Zaïre. Cahiers des Sciences Humaines 25 : 147-158.

Harms R. 1999 - Games against nature: An eco-cultural history of the Nunu of equatorial Africa. Cambridge, Cambridge University Press, 276 p.

Koppert G.J.A., Dounias E., Froment A. \& Pasquet P. 1993 - Food consumption in the forest populations of the southern coastal area of Cameroon. In Hladik C.M., Pagezy H., Linares O.F., Hladik A., Semple A. \& Hadley M. (Ed.), Tropical forests, people and food. Biocultural interactions and applications to development. Paris : Unesco-Parthenon, Man and Biosphere serie : 295-310.

Letouzey R. 1985 - Notice de la carte phytogéographique du Cameroun au 1:500 000 (1985). Domaine de la forêt dense humide toujours verte (p. 95-142 avec groupements numéro 185-267). Toulouse, Institut de la Carte Internationale de la Végétation.

McSweeney K 2003 - Tropical forests as safety nets? The relative importance of forest product sale as smallholder insurance, Eastern Honduras. Paper presented at The International Conference on Rural Livelihoods, Forests and Biodiversity, Bonn, 19-23 May 2003, 26 p.

Ménard L, Carrière S. \& Dounias E. 2009 - Cocoa smallholder farming in southern Cameroon: Resilient to change? Presentation at the Second World Congress of Agroforestry, 23-28 August 2009, Nairobi, Kenya.

Ménard L. 2010 - Evolution des agroforêts cacaoyères du sud Cameroun forestier, analyse agro/ ethnoécologique comparée chez les Mvae et les Ntumu de la boucle du Ntem. Master of Science, Montpellier, AgroParisTech Engref-IRD, $61 \mathrm{p}$.

Oishi T. 2014 - Sharing hunger and sharing food: staple food procurement in long-term fishing expedition of Bakwele horticulturalists in southeastern Cameroon. African Studies Monographs, Supplementary Issue 47 : 59-72.

Oishi T. 2016 - Ethnoecology and ethnomedicinal use of fish among the Bakwele of southeastern Cameroon. Revue d'ethnoécologie 10.

Oishi T. \& Hagiwara M. 2015 - A preliminary report on the distribution of freshwater fish of the Congo River: based on the observation of local markets in Brazzaville, Republic of the Congo. African Study Monographs. Supplementary Issue 51 : 93-105.

Olivry J.-C. - 1988 Fleuves et rivières du Cameroun. Paris, MESRES-ORSTOM, 733 p. 
Pagezy H. 1988 - Coping with uncertainty in food supply among the Oto and the Twa living in the equatorial flooded forest near Lake Tumba, Zaire. In Garine I de \& Harrison G.A. (Ed.), Coping with uncertainty in food supply. Oxford, Clarendon Press : 175-209.

Pagezy H. 2006 - Le contexte magico-religieux de la pêche au lac Tumba: entre le "normal" et l'insolite. Journal des Africanistes 76 : 44-62.

Pagezy H. \& Guagliardo V. 1992 - Rôle du surnaturel dans la gestion des ressources naturelles chez les Ntomba du Zaïre. Ecologie Humaine 10 : 69-77.

Pagezy H. \& Nzouango D. 1998 - La pêche aux crevettes sur la Lobé face à la demande des villes : changement de pratiques et conséquences sur la gestion durable des ressources. In Bley D., Champaud J., Baudot P., Brun B., Pagezy H. \& Vernazza-Licht N. (Ed.), Villes du Sud et environnement. Châteauneuf-de-Grasse, APFT/Éditions de Bergier : 156-170.

Panyella A. 1959 - Esquema de etnologia de los Fang Ntumu de la Guinea Española. Madrid, Instituto de Estudios Africanos, $78 \mathrm{p}$.

Paugy D., Levêque C. \& Mouas I. (Ed.) 2011 - Poissons d'Afrique et peuples de l'eau. Marseille, IRD Éditions, 320 p.

Pauly D. 1997 - Small-scale fisheries in the tropics: marginality, marginalisation, and some implications for fisheries management. In Pikitch E.K., Huppert D.D. \& Sissenwine M.P. (Ed.), Global trends: fisheries management. Bethesda, Maryland, American Fisheries Society : 40-49.

Plancke C. 2011 - The spirit's wish: possession trance and female power among the Punu of Congo-Brazzaville. Journal of Religion in Africa 41 : 366-395.

Platteau J.-P. 1989 - The dynamics of fisheries development in developing countries: a general overview. Development and Change 20 (4) : 565-597.

Smith L., Khoa S. \& Lorenzen K. 2005 - Livelihood functions of inland fisheries: policy implications in developing countries. Water Policy 7 : 359-383.

Tessmann G. 1913 - Die Pangwe- Völkerkundliche Monographie eines westafrikanischen Negerstammes Ergebnisse des Lübecker Pangwe-Expedition 1907-1909 und früherer Forschungen 1904-1907. Berlin, Ernst Wasmuth, Erster Band 275 p., Zweiter Band 402 p.

Thorbjarnarson J.B. \& Eaton M.J. 2004 - Preliminary examination of crocodile bushmeat issues in the Republic of Congo and Gabon. In Crocodiles. Proceedings of the 17th Working Meeting of the IUCNSSC Crocodile Specialist Group. Gland, IUCN : 236-247.

Thorpe A., Reid C., van Anrooy R. \& Brugère C. 2005 - When fisheries influence national policymaking: an analysis of the national development strategies of major fish-producing nations in the developing world. Marine Policies 29 : 211-222.

Vinceti B., Eyzaguirre P. \& Johns T. 2008 - The nutritional role of forest plant foods for rural communities. In Colfer C.J.P. (Ed.), Human health and forests: a global overview of issues, practice and policy. London, Earthscan : 63-96.

Welcomme R.L. 1975 - The fisheries ecology of African floodplains. Rome, FAO, CIFA Technical Paper, $51 \mathrm{p}$.

Welcomme R.L. 2011 - An overview of global inland fish catch statistics. ICES Journal of Marine Science 68 : 1751-1756.

Welcomme R.L., Cowx I.G., Coates D., Béné C., Funge-Smith S., Halls A. \& Lorenzen K. 2010 - Inland capture fisheries. Philosophical Transactions of the Royal Society B: Biological Sciences $365: 2881-2896$. 
Wunder S., Börner J. \& Shively G. 2014 - Safety nets, gap filling and forests: A global-comparative perspective. World Development 64: S29-S42. DOI: 10.1016/j.worlddev.2014.03.005

Yasuoka H., Hirai M., Kamgaing T.O.W., Dzefack Z.C.B., Kamdoum E.C.B. \& Bobo K.S.

2015 - Changes in the composition of hunting catches in southeastern Cameroon: a promising approach for collaborative wildlife management between ecologists and local hunters. Ecology and Society $20(4): 25$.

\section{APPENDIXES}

\section{Lexicon of the aquatic fauna captured by the Mvae and the Ntumu}

\begin{tabular}{|c|c|c|c|c|}
\hline Family & Scientific name & Common name & Ntumu name & Mvae Name \\
\hline \multicolumn{5}{|l|}{ Fishes } \\
\hline \multirow{12}{*}{ Alestidae } & Alestes barezome Joannis, 1835 & Robber tetra & $\operatorname{mben}(\dot{m}-/ m i-)$ & yeba (è-/bi-) \\
\hline & Alestes macrophthalmus Günther, 1867 & Torpedo robber & salekele (o/bè-) & \\
\hline & Bricynus macrolepidotus Valenciennes, 1849 & True big-scale tetra & kos (o/be- - ) & \\
\hline & Bricynus opisthotaenia Boulenger, 1903 & African tetra & $\operatorname{vep}(\hat{a} / b \dot{a})$ & vep (o/be-) \\
\hline & Brycinus cf. Iongipinnis Günther, 1864 & Long-finned Tetra & mvàà (o/bè-) nkyêmet (o/mil-) & \\
\hline & Bycinus macrolepidotus Valenciennes, 1850 & Big Scale Tetra & $\operatorname{kos}(\theta / \mathrm{be}-)$ & \\
\hline & Brycinus tessmannii Pappenheim, 1911 & African tetra & nkyżmé (ø/mi-) & nkyźmé (ø/mi-) \\
\hline & Bycinus taeniurus Gunther, 1867 & African tetra & & ngenda (o/mi-) \\
\hline & Bryconaethiops macrops Boulenger, 1920 & African tetra & kira (ø/ø) & kira (ø/\%) \\
\hline & Micralestes occidentalis Günther, 1899 & Redin Congo-tetra & & mvàà (o/bè-) \\
\hline & Micralestes sp. 1 Boulenger, 1899 & African tetra & mvàa (ø/bè-) èkãn & \\
\hline & Micralestes sp. 2 Boulenger, 1899 & African tetra & mvàa (e/bè-) nttżm & \\
\hline \multirow{2}{*}{ Amphilidae } & Phractura brevicauda Boulenger, 1911 & Loach cattish & भร)|ล (ด/bè-) & lé (d/bè-) \\
\hline & Phractura intermedia Boulenger, 1911 & Loach cattish & & kwala (e-/Di-) \\
\hline \multirow{2}{*}{ Anabantidae } & Clenopoma cf. maculatum Thominot, 1886 & African labyrinth fishes & fila (e-/bi-) & wung (a/me-) \\
\hline & Clenopoma sp. W.K.H. Peters, 1844 & African labyrinth fishes & fila (è-lbi-) & wung (à/mè-) \\
\hline Aplocheilidae & Epiplatys sp. T.N. Gill, 1862 & Clown killi & & nbón (ब/\%) \\
\hline Arapaimidae & Heterotis niloticus G. Cuvier, 1829 & African arowana & & kanga (à/mè-) \\
\hline \multirow{6}{*}{ Bagridae } & Auchenoglanis cf guirali Thominot, 1886 & Claroteid cattish & nsin dōo (ø/mà-) & nsin dōo \\
\hline & Auchenoglanis cf occidentalls Valenciennes, 1840 & Girafte cattish & $\operatorname{vos}(\mathrm{e}-/ \mathrm{bi}-)$ & vus (e-/Di-) \\
\hline & Auchenoglanis sp. 1 Günther, 1865 & Claroteid catfish & & minvòn (mì-mi-) \\
\hline & Auchenoglanis sp. 2 Günther, 1865 & Claroteid cattish & & ndöò \\
\hline & Chrysichthys nigrodigtatus Lacepedde, 1803 & Siver African catifish & & kyenda ( $(/ \mathrm{mi}-)$ \\
\hline & Leptoglanis sp. Boulenger, 1902 & Loach cattish & 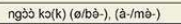 & \\
\hline Channidae & Parachannna obscura Gunther, 1861 & Obscure snakehead & kpckwos (ä/mà-) & nzimba (ø/bè-) \\
\hline \multirow{11}{*}{ Cichlidae } & Hemichromis fasciatus W.K.H. Peters, 1857 & Banded jewellish & sojo $\left(\hat{a}-1 / b^{\prime} \dot{e}-\right)$ & sojo (è-/bè-), evin esoo \\
\hline & Oreochromis niloticus Linnaeus, 1758 & Nile tlapia & 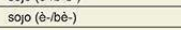 & \\
\hline & Pelmatochromis sp. Steindachner, 1894 & Tilapiine-cichlid fish & & evel anu afyèràk \\
\hline & Pelmatochromis ocellifer Boulenger, 1899 & Trlapiine-cichlid fish & & àtyàrák \\
\hline & Sarotherodon mvogoi Thys van den Audenaerde, 1965 & Trlapine-cichlid fish & & akkin \\
\hline & Steatocranus sp. Boulenger, 1899 & Blockhead cichlid & & nkangolà (o/bè-) \\
\hline & Tilapia nyongana Thys v van den Audenaerde, 1971 & Tilapia & àkùn & àkùn \\
\hline & Tilapia sp. A. Smith, 1840 & Tilapia & sojo (ê-lbè-) & sojo $(\hat{e}-\mathrm{A} b \mathrm{e}-\mathrm{e})$ \\
\hline & Indeterminata & Cichlid & dwon & \\
\hline & Indeterminata & Cichlid & ngomák kwos & \\
\hline & Indeterminata & Cichlid & & $100(\mathrm{e}-1 \mathrm{bi}-)$ \\
\hline Citharinidae & Citharichtys stampflii Steindachner, 1894 & Smooth flounder & ko20(è-bi-) & koro (è-l-bi-) \\
\hline \multirow{3}{*}{ Clariidae } & Clarias camerunensis Lönnberg, 1895 & Catfish & ngaso (o/me-) & ngajo (o/me-) \\
\hline & Clarias pachynema Boulenger, 1903 & Cattish & mvas (olbè-) & mvas (o/bo-) \\
\hline & Clarias sp. Scopoli, 1777 & Cattish & & mù̀ \\
\hline \multirow{3}{*}{ Claroteidae } & Parauchenoglanis altipinnis Boulenger, 1911 & Claroteid catrish & ndojo (e/bè-) & \\
\hline & Parauchenoglanis pantherinus Pellegrin, 1929 & Claroteid catfish & nsim ndojo (a/be-) & \\
\hline & Parauchenoglanis sp. Boulenger, 1911 & Claroteid catfish & & ebonde \\
\hline
\end{tabular}




\begin{tabular}{|c|c|c|c|c|}
\hline Family & Scientific name & Common name & Ntumu name & Mvae Name \\
\hline \multicolumn{5}{|l|}{ Fishes } \\
\hline \multirow{15}{*}{ Cyprinicae } & Barbus brazzai Pellegrin, 1901 & Ray-finned fish & ingwoóngừù (n-lbe-) & \\
\hline & Barbus aspilus Boulenger, 1907 & Ray-finned fish & kpwiét (o/bi-), mfyorz (o/bè-) & nkpwa (a/bi-) \\
\hline & Barbus guirali Thominot, 1886 & Ray-finned fish & $\operatorname{mvừz~(a/bè-)~}$ & mvèż ( (ø/bè-) \\
\hline & Barbus sp. 1 Cuvier \& Cloquet, 1816 & Ray-finned fish & & aloo \\
\hline & Barbus sp. 2 Cuvier \& Cloquet, 1816 & Ray-finned fish & & okal (o/bè-) mva (o/bè-) \\
\hline & Barbus sp. 3 Cuvier \& Cloquet, 1816 & Ray-finned fish & & fưfun (è-/bè-) \\
\hline & Barbus sp. 4 Cuvier \& Cloquet, 1816 & Ray-finned fish & & mangolo ( $(/ / 0)$ \\
\hline & Labeo batesii Boulenger, 1911 & Ray-finned fish & mbyers (m-/mi-) & m.mbers $(\mathrm{m}-/ \mathrm{mi}-)$ \\
\hline & Labeobarbus batesii Boulenger, 1903 & Ray-finned fish & mvok (o/be-) & \\
\hline & Labeobarbus ct. malacanthus Pappenheim, 1911 & Ray-finned fish & mfio (o/ba-) & \\
\hline & Labeobarbus progennys Boulenger, 1903 & Ray-finned fish & koko (e-10e-) & \\
\hline & Raiamas buchholzi W.K.H. Peters, 1876 & Ray-finned fish & sàmà (è-/mè-), sảmbalà (è-/mè-) & sảmà (è-lmè-)= sám (è-/mè-) \\
\hline & Varicorhimus sandersi Boulenger, 1912 & Ray-finned fish & mfio (0/pe-) & \\
\hline & Varicorminus steindachneri Boulenger, 1910 & Ray-finned fish & $n \operatorname{lin}(0 / \mathrm{be}-\mathrm{-})$ & lingi (o/pe-) \\
\hline & Vancorhinus sp. Rüppell, 1835 & Ray-fined fish & mfio (o/be- $)$ & \\
\hline \multirow{5}{*}{ Distichodontidae } & Distichodus cf. engycephalus Günther, 1864 & Longsnout fish & mfra (a/be-) & \\
\hline & Distichodus hypostomatus Pellegrin, 1900 & Longsnout fish & mbong (a/be-) ntem & \\
\hline & Distichodus notosopilus Gunnther, 1864 & Longsnout fish & kojo (è-b) - & \\
\hline & Distichoodus sp. 1 J.P. Müler \& Troschel, 1844 & Longsnout fish & mboon (o/ & mbun (o/o-) \\
\hline & Distichodus sp. 2 J.P. Maller \& Troschel, 1844 & Longsnout fish & mfra (a/be-) & mfika (o/be-) \\
\hline \multirow{2}{*}{ Eleotridae } & Eleotris vitata A.HA. Dumérii, 1861 & Bigmouth sleeper & & atorok \\
\hline & Kribia sp. Herre, 1946 & Sleeper goby & & atti \\
\hline Hepsetidae & Hepsetus lineata Pellegrin, 1926 & African pike & nsojo (a/be-) & obán / nsoóo \\
\hline Malapteruridae & Malaptuterunus beninen sis Murray, 1855 & Electric cattish & תen (à-mè-) & תinn (a-me-me-) \\
\hline Mastacembeliodae & Caecomastacembelus cryptacanthus Günter, 1867 & Spiny eel fish & nwón (o/\%) & nwón (ø/\%) \\
\hline & Atopochilus savorgnani Sauvage, 1879 & Upside-down cattish & mvoro (ø/pè-) & \\
\hline & Synodontis albolineata Pellegrin, 1924 & Mustard cattish & ngòngj (a/bè-) & ngòngj (a/bè-) \\
\hline & Synodontis tessmanni Pappenheim, 1911 & Upside-down cattish & ngìngj (o/be-) & ngings (o/be-) \\
\hline Mochokidae & Chiloglanis batesi Boulenger, 1904 & Upside-down cattish & & nkolmekok \\
\hline & Chiloglanis sp. W.K.H. Peters, 1868 & Upside-down catfish & mvora (o/o) & \\
\hline & Microsynodontis batesii Boulenger, 1903 & Upside-down cattish & nbàn (à-/mè-) & Đbàn (à-/mè-) \\
\hline & Synodontis sp. G. Cuvier, 1816 & Eatherfin squeaker & mvo? mè sam & \\
\hline & Boulengeromyrus knoepffferi Taverne \& Géry, 1968 & Elephantish & mbàmà żjk (o/bè-) & \\
\hline & Brenomyrus ebumeensis Bigome, 1991 & Elephantish & ntototsm (n-m/mi-) & ntotjom (n-/mi-) \\
\hline & Isichthys henny Gill, 1863 & Elephantish & & 1010 \\
\hline & Vindomyrus opdenboschi Taverne et Géry, 1975 & Elephantisis & mbang (min-mè-) & \\
\hline Mormyridae & Marcusenius mooni Günther, 1867 & Elephantish & nən (à-/mè-) & nen (à-/mè-) \\
\hline & Marcusenius ntemensis Pellegrin, 1927 & Elephantish & ntottim (nh-mi- & 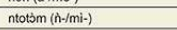 \\
\hline & Mommyrops zancliorostrisis Günther, 1867 & Bottlenose fish & ndonlojo (a/bè-) & ndolo (o/bè-) \\
\hline & Paramormyrops kingsileyea Gunther, 1896 & Elephantifish & n Spence Bate, 1868 nken & \\
\hline & Petrocephalus simus Sauvage, 1879 & Elephantisish & & fyat \\
\hline Ophichthyidae & Dalophis cephalopeltis Bleeker, 1863 & «Baie de Loangon eel & & bogo \\
\hline Family & Scientific name & Common name & Ntumu name & Mvae Name \\
\hline Fishes & & & & \\
\hline & Schilbe multitaeniatus Pellegrin, 1913 & Schibid cattish & kyg $(0-100-)$ & \\
\hline & Schilbe sp. 10 Ken, 1817 & Schilbid cattish & & ekida \\
\hline Schilbeidae & Schilbe sp. 2 Oken, 1817 & Schilibid cattish & & mmbya \\
\hline & Schilibe sp. 3 Oken, 1817 & Schibid catfish & & nkat \\
\hline & Schilbe sp. 4 Oken, 1817 & Schilibid cattish & & osop \\
\hline Shellfishes & & & & \\
\hline & Macrobrachium sp. Spence Bate, 1868 & Freshwater shrimp & ngwàs (n/mi-) & ngwàs (n-lmi-) \\
\hline & Macrobrachium sp. Spence Bate, 1868 & Freshwater shrimp & $\sin (\sigma / 0)$ & $\sin (\theta / \theta)$ \\
\hline Palaemonidae & Macrobrachium sp. Spence Bate, 1868 & Freshwater shrimp & & mokolo a ndenden \\
\hline & Macrobrachium sp. Spence Bate, 1868 & Freshwater shrimp & & mvobolon ngwás \\
\hline & Macrobrachium sp. Spence Bate, 1866 & Freshwater shrimp & & ngase fân \\
\hline Alpheidae & Potamalpheops monodi Sollaud, 1932 & Alpheid shrimp & & $\sin$ \\
\hline Corciniso & Cardisoma armatum Herklots, 1851 & Crab & kara (o/be-) & kara (ø//be-) \\
\hline Carcinidae & Indeterminata & Crab & & kengele \\
\hline Gastropod mollusks & & & & \\
\hline & Achatina sp. 1 Lamarck, 1799 & Snail & & akuk \\
\hline . & Achatina sp. 2 Lamarck, 1799 & Snail & & ngon kwen \\
\hline Achatinidae & Achatina sp. 3 Lamarck, 1799 & Snail & & ebos \\
\hline & Achatina sp. 4 Lamarck, 1799 & Snail & & nsondo \\
\hline Batracians & & & & \\
\hline Butonidae & Amietophynus supercilianis Boulenger, 1888 & Cameroon toad & & mvon \\
\hline Bufonidae & Bufo sp. Laurenti, 1768 & Toad & & baba \\
\hline & Scotobleps gabonicus Boulenger, 1900 & Gaboon forest frog & & bap (à-lme-) \\
\hline Hyperolidae & Trichobatrachus robustus Boulenger, 1900 & Hairy frog & & korodzono (o-bil-) \\
\hline Ranidae & Conrava goliath Boulenger, 1906 & Goliath frog & nàmwàa (o/o) & 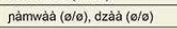 \\
\hline & Eleutherodactylus albolabris Taylor, 1943 & White-lipped chirping frog & & dzż (e-/poji-) \\
\hline Reptiles & & & & \\
\hline Boidae & Python sebae Gmelin, 1788 & African rock python & & mvom \\
\hline & Mecistops cataphractus Cuvier, 1825 & Slender-snouted crocodile & & nkan \\
\hline Crocodilidae & Osteoleemus tetraspis Cope, 1860 & Dwarf crocodile & & nkòm (n-lmi-) \\
\hline Elapidae & Naja annulata Buchholz and Peters, 1876 & Banded water cobra & & $\operatorname{lom}(\hat{\mathrm{e}}-1 / \mathrm{bi}-)$ \\
\hline Pelomedusidae & Pelusios gabonensis Duméril, 1856 & African forest turtle & & kul oswin \\
\hline Testudinidae & Kinixys sp. Bell 1827 & Hinged tortoise & & nduka \\
\hline & Cycloderma aubryi Duméril, 1856 & Aubry's flapshell turte & & sa kola \\
\hline Trionychidaa & Trionyx triunguis Forskàl, 1775 & African sofftshell turtle & & mafebe \\
\hline Varanidae & Varanus niloticus Linnaeus, 1758 & Nile monitor & & nkaa \\
\hline Mammals & & & & \\
\hline Mustelidae & Aonyx capensis congicus Lönnberg, 1910 & Cameroon clawless otter & & bán (a-mete-) \\
\hline Tenrecidae & Potamogale velox Du Chaillu, 1860 & Giant otter shrew & & dzás (o/o) \\
\hline
\end{tabular}

\section{NOTES}

1. Vernacular terms in Fang languages are written phonetically using the International Phonetic Alphabet. Mentioned in pairs between brackets after the radical are the prefixes expressing the singular and the plural forms. Absence of tonal accent on some vowels indicates a medium tone. 
2. Mami Wata is the Mother of the Waters. Half-woman half-fish, half-terrestrial half-aquatic, it is a strong water spirit and venerated divinity throughout the Central part of the African continent.

3. The local names of all described fishing methods are recapitulated in Figure 5.

4. Complete scientific, common and vernacular names of the freshwater fauna observed in the Ntem river watershed are recapitulated as a lexicon in Annex.

\section{ABSTRACTS}

The Mvae and the Ntumu, two African rainforest ethnic groups belonging to same Fang linguistic sub-group, live together as good neighbors in the Ntem watershed of southern Cameroon. Like most forest dwellers in the Congo Basin, these two societies have implemented a multi-active type of subsistence economy: hunting, trapping, gathering and fishing are practiced in addition to a predominant slash-and-burn agriculture. The aim of this paper is to emphasize that these ethnic groups, which do not have fishery as their most salient production domain, have nevertheless acquired a remarkable expertise in wild fishery, notably through a diversity of techniques and socio-ecological conditions of practice. The sizable variety of fishing methods takes advantage of the great vascularity of the hydrographic network and involves in a complementary way all the members of the community - young and old, of both genders, in solo, in pairs or in larger groups of participants. This large range of possibilities ensures a continuous provision of fish over the year and establishes inland capture fishery as a real safety net that can provide - in all circumstances and in sufficient quantities - resources that are culturally valued, that are an appreciable extra-source of income, and whose nutritional role is acknowledged. Despite of being the pervasive basis of the subsistence economy of forest peoples in Central Africa, the contribution of inland capture fishery to the livelihoods of Congo basin forest dwellers remains unobtrusive and is overlooked by development agencies.

Mvae et Ntumu, deux ethnies forestières appartenant au même sous-groupe linguistique des Fang, vivent en bon voisinage dans le bassin hydrographique du Ntem. Comme la majeure partie des habitants forestiers du Bassin du Congo, ces deux peuples ont une économie de subsistance de type pluriactif: chasse, piégeage, cueillette et pêche sont pratiqués en complément d'une agriculture itinérante sur brûlis prédominante. L'objectif de cet article est de montrer que ces sociétés qui n'ont pourtant pas la pêche comme domaine de production de prédilection, disposent cependant d'une remarquable expertise en la matière, au travers notamment de la diversité des techniques et des modalités socio-écologiques de réalisation. La palette technique étendue des pratiques de pêche tire profit de la grande vascularisation du réseau hydrographique et implique de manière complémentaire l'ensemble des acteurs de la société - jeunes et moins jeunes, des deux genres, en solitaire, en binôme ou en groupes plus nombreux. Cet éventail des possibles est en mesure d'assurer un ravitaillement continu sur l'année et érige la pêche en véritable filet de sécurité à même de fournir, en toutes circonstances et en quantités suffisantes, des ressources culturellement valorisées, pourvoyeuses d'un revenu d'appoint, et dont la qualité nutritionnelle est reconnue. La pêche en eau douce est un fondement discret de l'économie de subsistance des peuples forestiers d'Afrique centrale et continue d'être occultée par les agences de développement. 


\section{INDEX}

Mots-clés: techniques de pêche, catégories de cours d'eau, diversité, saisonnalité, filet de sécurité, économie de subsistance, forêt tropicale humide

Keywords: fishing techniques, inland water categories, diversity, seasonality, safety net, subsistence economy, Southern Cameroon, tropical rainforest, Ntem watershed, Mvae, Ntumu Population Mvae (Cameroun), Ntumu (Cameroun)

\section{AUTHORS}

\section{EDMOND DOUNIAS}

\section{IRD-CIFOR}

Centre d'Écologie Fonctionnelle et Évolutive (UMR5175 CEFE) - Campus CNRS, 1919 route de Mende - 34293 Montpellier cedex 5, France

edmond.dounias@ird.fr

\section{SERGE COGELS}

Faculté de Philosophie et Sciences Sociales - Université Libre de Bruxelles - Campus de Solbosh CP124 Avenue F.D. Roosevelt 50 - 1050 Bruxelles, Belgique scogels@ulb.ac.be

\section{SERGES MVÉ MBIDA}

Laboratoire des Ressources Halieutiques - Université de Douala - PO BOX 2701 - Douala, Cameroun

sergesmbida@gmail.com

\section{STÉPHANIE CARRIÈRE}

IRD, UMR 220 GRED - Université Paul-Valéry Montpellier 3, Site Saint Charles - Rue du Professeur Henri Serre - 34080 Montpellier, France stephanie.carriere@ird.fr 